Provided for non-commercial research and education use. Not for reproduction, distribution or commercial use.

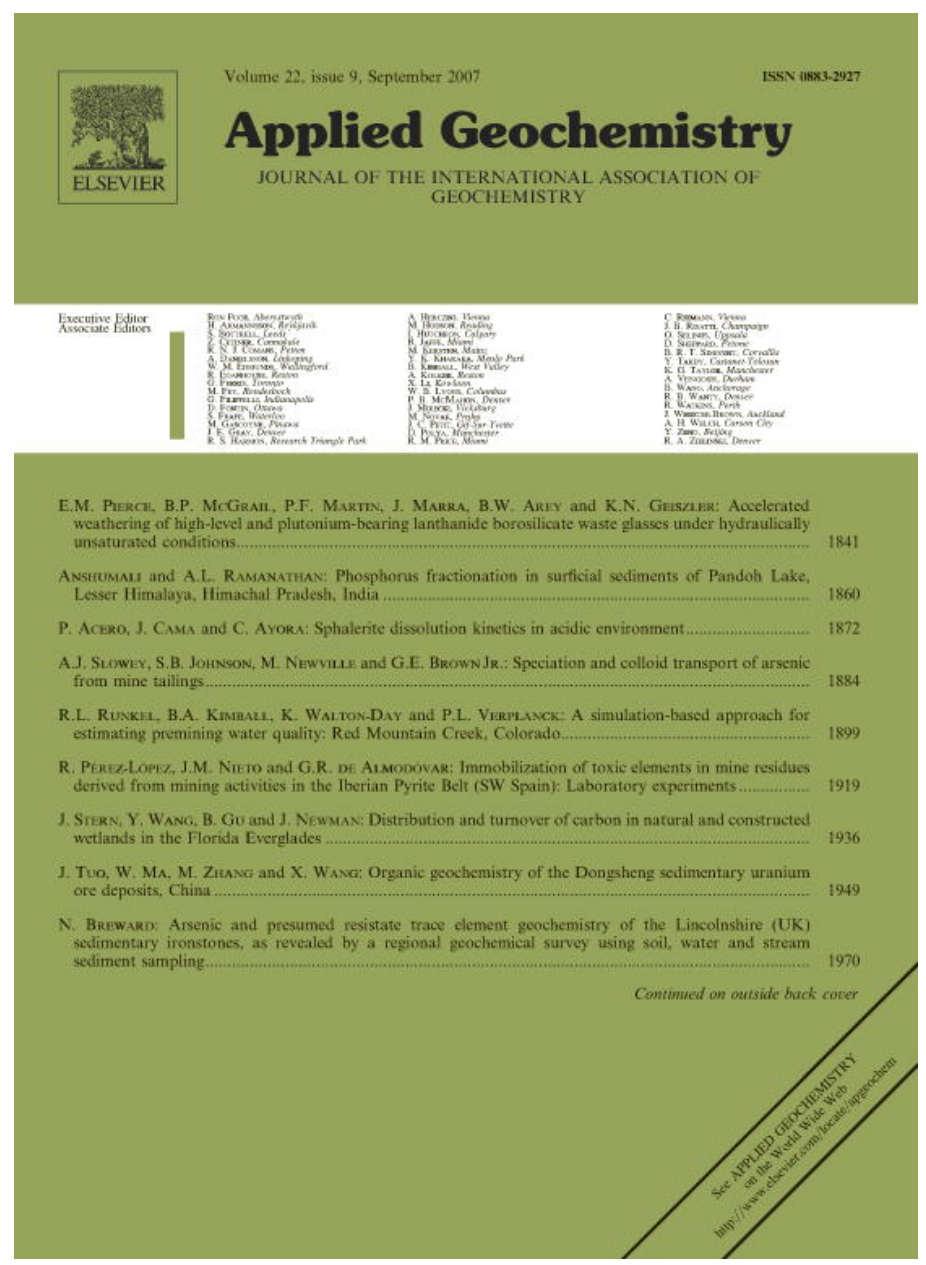

This article was published in an Elsevier journal. The attached copy

is furnished to the author for non-commercial research and education use, including for instruction at the author's institution, sharing with colleagues and providing to institution administration.

Other uses, including reproduction and distribution, or selling or licensing copies, or posting to personal, institutional or third party websites are prohibited.

In most cases authors are permitted to post their version of the article (e.g. in Word or Tex form) to their personal website or institutional repository. Authors requiring further information regarding Elsevier's archiving and manuscript policies are encouraged to visit:

http://www.elsevier.com/copyright 


\title{
Arsenic and presumed resistate trace element geochemistry of the Lincolnshire (UK) sedimentary ironstones, as revealed by a regional geochemical survey using soil, water and stream sediment sampling
}

\author{
Neil Breward \\ British Geological Survey, Keyworth, Nottingham NG12, 5GG, UK \\ Received 31 October 2006; accepted 8 March 2007 \\ Editorial handling by C. Reimann \\ Available online 10 May 2007
}

\begin{abstract}
A regional geochemical survey using soils, stream sediment and stream water sampling revealed multi-element geochemical anomalies, though of low environmental mobility, associated with Mesozoic sedimentary ironstones in Lincolnshire, UK. The most prominent of these anomalies were of As and V in soils and sediments, but elevated levels of elements such as $\mathrm{Cr}, \mathrm{La}, \mathrm{Ce}$ and $\mathrm{Th}$ were also observed. These were initially thought to be part of a residual resistate element or heavymineral suite, but careful examination suggests that these too may be primarily associated with the process of Fe oxide precipitation during the initial formation of the ironstones.

Crown Copyright $\Subset 2007$ Published by Elsevier Ltd. All rights reserved.
\end{abstract}

\section{Introduction}

During the preparation of the Regional Geochemical Atlas of the Humber-Trent region (British Geological Survey, 2007) for the British Geological Survey's Geochemical Baseline Survey of the Environment (G-BASE) project, a series of strong and distinctive geochemical patterns for a number of elements were observed over sedimentary ironstone outcrops in Lincolnshire, U.K., and are worthy of special attention. Possible explanations for the patterns observed are given and examined.

E-mail address: nbr@bgs.ac.uk
The English county of Lincolnshire hosts several Mesozoic sedimentary ironstone formations, notably the Frodingham ironstone at Scunthorpe, the Marlstone Rock in the south near Grantham, and the Claxby ironstone which runs below the escarpment of the Wolds from Spilsby north to Caistor (Fig. 1). The former are of Lower Jurassic age, the latter is of Lower Cretaceous age, but all show some interesting geochemical characteristics. Each of these named 'ironstone formations' contain ferruginous sandstones, limestones and mudstones in addition to beds of true ironstones which generally contain greater than $30 \%$ by weight $\mathrm{Fe}$ oxides. Sedimentary ironstones, other than the more problematic banded iron formations, are mainly lagoonal 


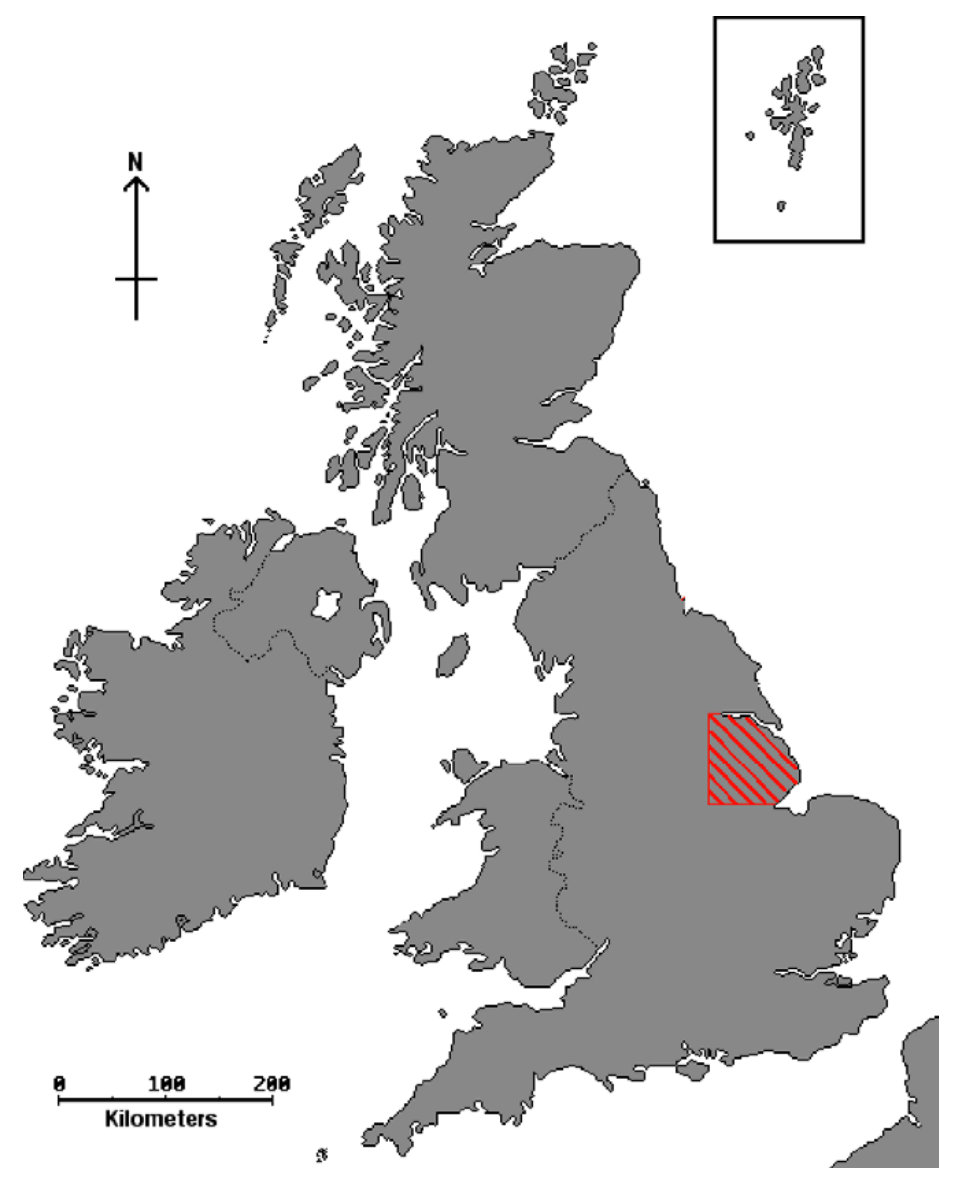

Fig. 1. Sketch map of the 'solid' geology of Lincolnshire, and location within the UK.

or shallow-water marine deposits where conditions allow movement of free reduced $\mathrm{Fe}$ in solution as $\mathrm{Fe}_{(\mathrm{aq})}^{2+}$ or as colloidal $\mathrm{Fe}^{(\mathrm{III})}$ complexes and its precipitation in a variety of insoluble $\mathrm{Fe}^{(\mathrm{II})}$ and $\mathrm{Fe}^{(\mathrm{III})}$ compounds, minerals such as goethite, limonite, siderite, vivianite and chamosite being the most common forms. The content of sulphides such as pyrite is variable, depending largely on the original organic-matter content of the lagoonal sediments and the $\mathrm{O}_{2}$ fugacity during sedimentation and precipitation, but is generally low in the ironstones under consideration here. This is significant, as pyrite can be an important carrier mineral for As, and such a readily-oxidised mineral would make the high As levels noted in this study much more mobile and potentially hazardous. A comprehensive explanation of sedimentary ironstone geochemistry can be found in Maynard (1983), and Young and Taylor (1989). Elevated levels of other elements are often found in sedimentary ironstones, notably $\mathrm{Ca}$ (as many are impure limestones) and $\mathrm{P}$, due to the reaction and sorption of solubilised organic and inor- ganic phosphate with $\mathrm{Fe}^{(\mathrm{III})}$ as hydroxide to give the highly insoluble $\mathrm{FePO}_{4}-\mathrm{Fe}(\mathrm{OH})_{3}$ additive complex. Strengite $\left(\mathrm{FePO}_{4} \cdot 2 \mathrm{H}_{2} \mathrm{O}\right)$ and ferrihydrite $\left(\mathrm{Fe}(\mathrm{OH})_{3}\right)$ can be considered to be the nominal end-members of this complex reaction series. One additional feature of this sorption reaction is that arsenate, $\mathrm{AsO}_{4}^{3-}$, can behave very similarly to phosphate, $\mathrm{PO}_{4}^{3-}$, under these conditions (cf. Dixit and Hering, 2003), and is also strongly sorbed to Fe hydroxide precipitates, resulting in elevated As levels in many sedimentary ironstones. Scorodite $\left(\mathrm{FeAsO}_{4} \cdot 2 \mathrm{H}_{2} \mathrm{O}\right)$ is analogous to strengite and similarly forms a complex reaction series with ferrihydrite, though the pure scorodite end-member is a rare mineral, which is only formed under strongly acidic conditions (e.g., in precipitates from acid mine drainage waters) and is not especially resistant to weathering. The peculiar sources and depositional environment of sedimentary ironstones may also lead to elevated levels of other trace elements, notably those which are commonly believed to have a 'resistate' mineral host, such as $\mathrm{Cr}, \mathrm{V}$, Th and the 


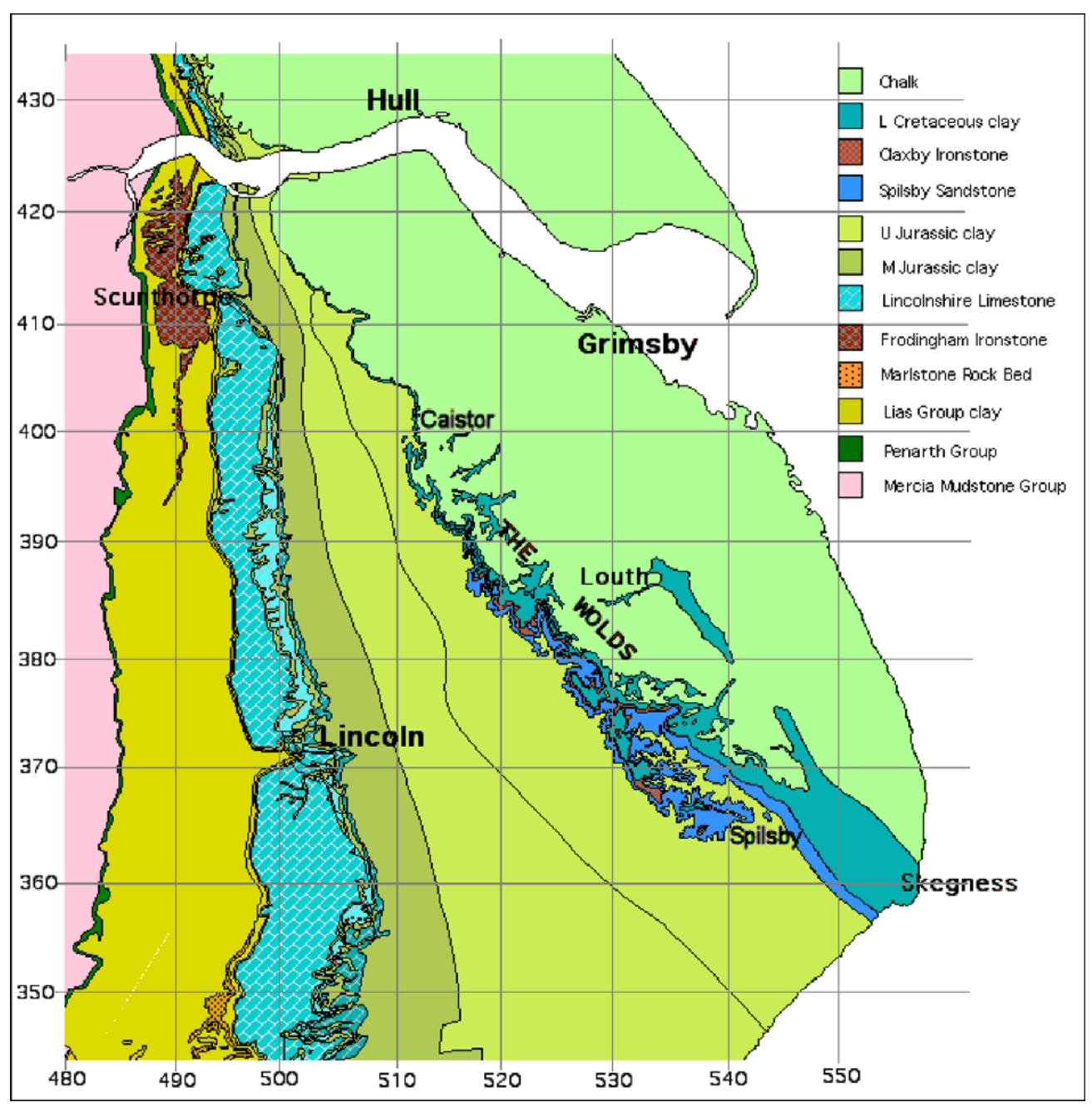

Fig. 1 (continued)

lanthanide elements $\mathrm{Ce}$ and La. Resistate elements are generally those whose host minerals are highly resistant to both chemical and physical weathering and hence have a very long residence time in soils and sediments. They are not necessarily the same as 'heavy minerals', though some heavy minerals are resistate.

\section{Topography and geological background}

Much of Lincolnshire is relatively low-lying, but with ridges of higher ground formed by a number of resistant geological formations, notably the Frodingham and Marlstone Rock Bed ironstones, the Lincolnshire Limestone, and the Chalk, which rises to over $160 \mathrm{~m}$ O.D. in the Wolds. A map of the 'solid' (Pre-Quaternary) geology is shown in Fig. 1, and shows a broadly north-south to NWSE pattern of Mesozoic sedimentary rocks ranging from the late Triassic (Mercia Mudstone Group) to the Upper Cretaceous (Chalk). The Quaternary geological map (Fig. 2) shows a variety of coverings of till and fluvioglacial sands and gravels, lacustrine, river and marine alluvium, peat and patches of blown sand. Holocene beach and Fen deposits, with smaller areas of anthropogenic 'made ground', complete the sequence. The stratigraphic relationships are shown in Figs. 3 and 4. Of the three major ironstones present, the Frodingham and Claxby beds are restricted to this area, while the Marlstone rock bed is more strongly developed to the south, notably in Leicestershire and Oxfordshire, and only crops out in the south of the area shown. The Frodingham ironstone provided rich $\mathrm{Fe}$ ores and was extensively mined until recently, forming the basis for the steel industry of Scunthorpe. The Claxby ironstone has a narrow outcrop at the base of the Chalk escarpment and was worked on a much smaller scale, e.g., at 


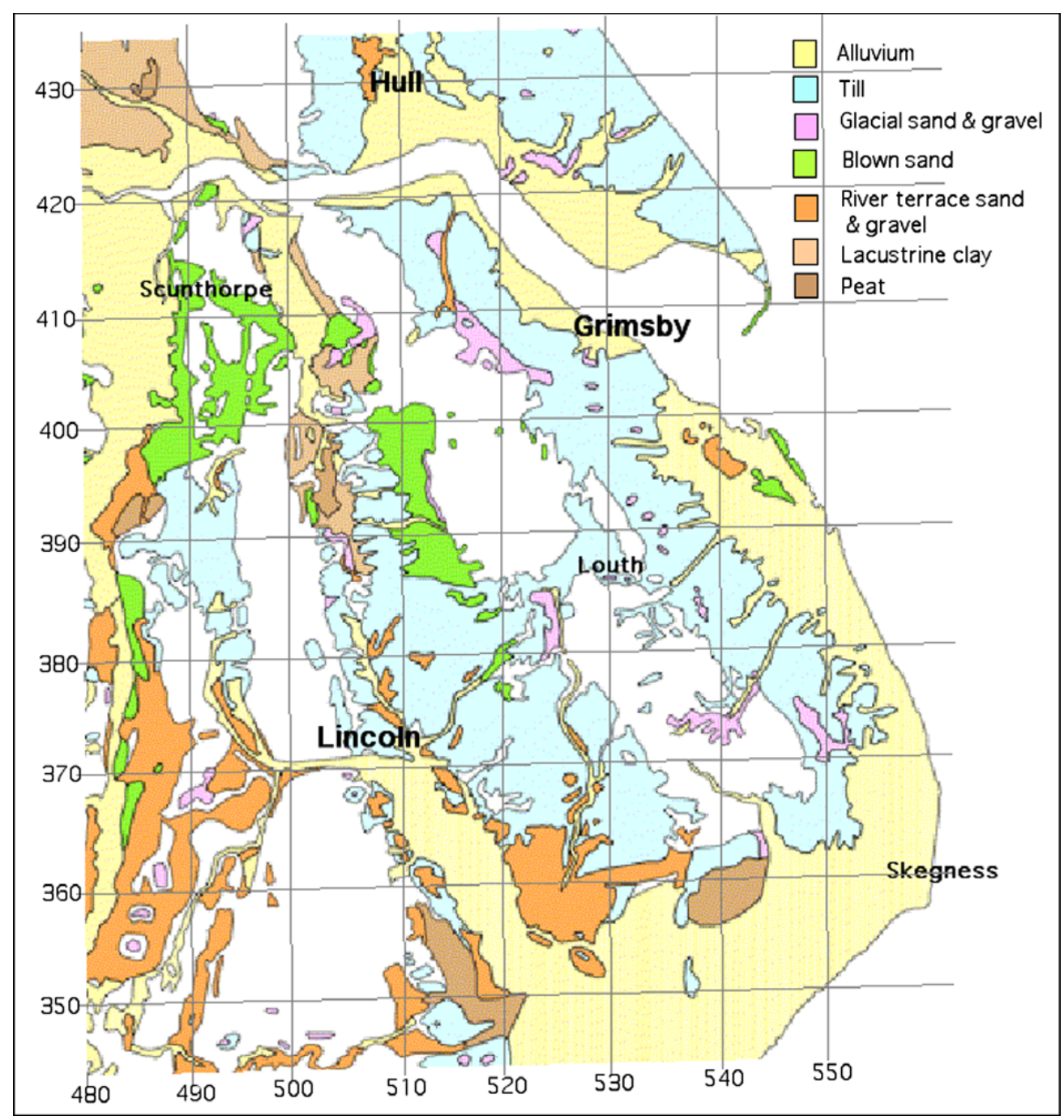

Fig. 2. Sketch map of the Quaternary geology of Lincolnshire.

Nettleton [NGR $\left.{ }^{5} 11,{ }^{4} 00\right]$ near Caistor, $20 \mathrm{~km}$ west of Grimsby, though the last mine here closed in 1969. The Marlstone rock bed was not worked in the area of interest, but was formerly mined in the area immediately to the south, for example between Grantham and Melton Mowbray. Other much thinner and impersistent ironstones are locally present at some other horizons within the Lias and Lower Cretaceous (e.g., within the Hundleby and Tealby Clays), but naturally show less prominent geochemical features at outcrop.

\section{The G-BASE regional geochemical survey project}

The Geochemical Baseline Survey of the Environment (G-BASE) is a long-established, high-resolution regional geochemical mapping project run by the British Geological Survey, aimed at making a complete geochemical survey for the whole UK landmass, and is described in detail in several publications (Johnson and Breward, 2004; Johnson et al., 2005). When sampling commenced in the late 1960s the work was stimulated by mineral exploration, but this high-resolution survey has evolved continuously and now has many environmental applications. The geochemical mapping, originally based on the collection of wet-sieved sub- $150 \mu \mathrm{m}$ drainage sediments at a target sampling density of one stream sediment sample per $\mathrm{km}^{2}$, has expanded to include the sampling and analysis of stream waters and soils (sub-2 mm) and now also includes the systematic sampling of urban soils (Fordyce et al., 2005). Solid materials are analysed for some 38 elements by X-ray fluorescence spectrometry (XRFS), and filtered stream waters $(0.45 \mu \mathrm{m})$ are analysed mainly by inductively-coupled plasma atomic emission spectrometry (ICP-AES) and inductively-coupled plasma 

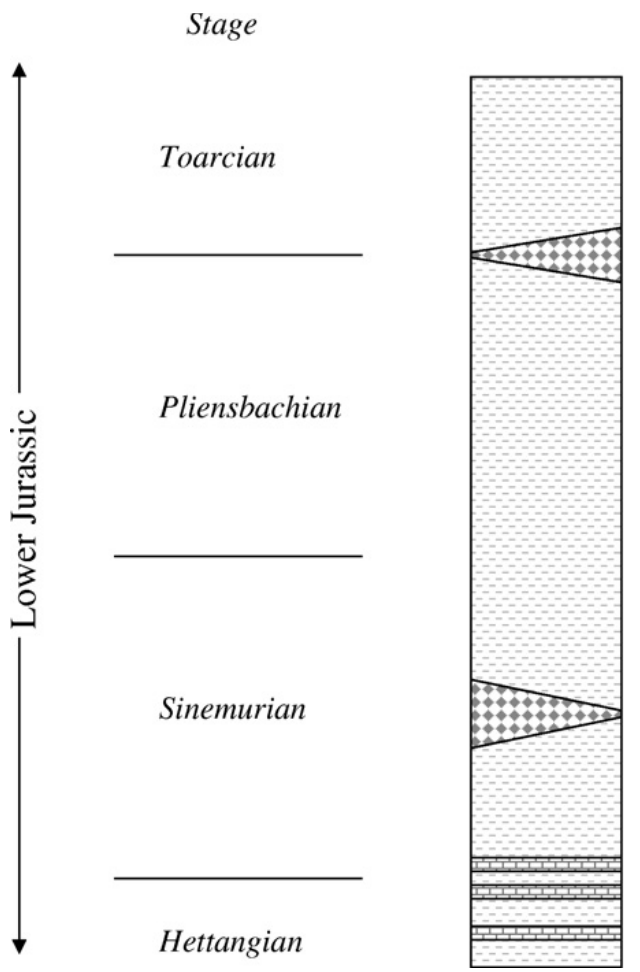

\author{
Lithostratigraphy \\ — Unconformaity \\ Whitby Mudstone Formation \\ ('Upper Lias Clays')
}

Marlstone Rock Formation

Charmouth Mudstone Fm.

Frodingham Ironstone Member

Scunthorpe Mudstone Fm.

(Clays)

(clays with thin limestones)
80-110 m

0-10 m

Thickness (approx.)

$20-40 \mathrm{~m}$

$1-4 \mathrm{~m}$

$30-40 \mathrm{~m}$

$30-40 \mathrm{~m}$

Fig. 3. Outline stratigraphy of the Lower Jurassic (Lias Group) in Lincolnshire.

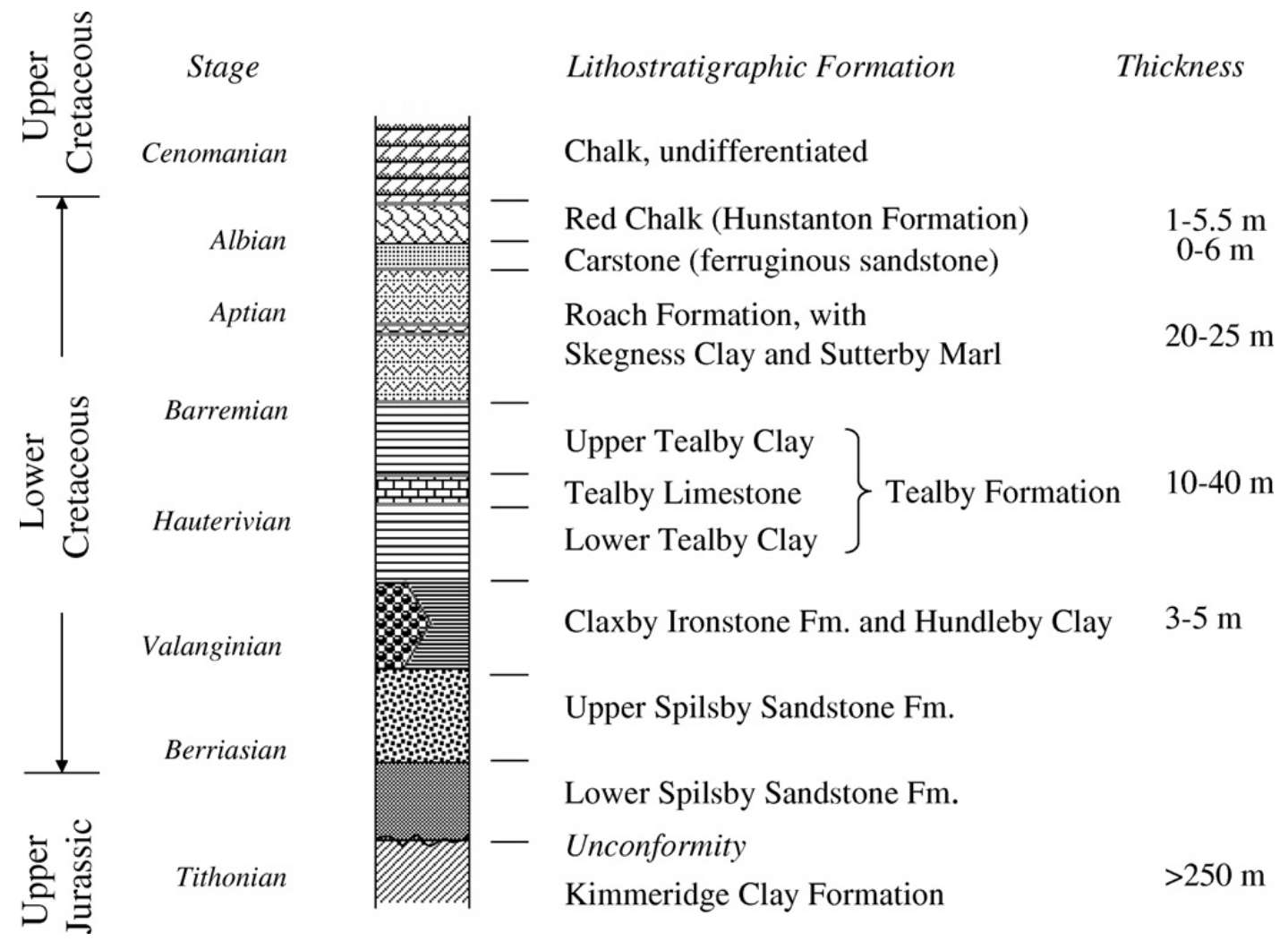

Fig. 4. Outline stratigraphy of the Upper Jurassic and Lower Cretaceous in Lincolnshire.

mass spectrometry (ICP-MS) for up to 35 elements, plus parameters such as $\mathrm{pH}$ and conductivity by other methods. Consequentially, with such a high resolution survey and wide range of elements, the project database now contains data for some five million individual element determinations. 
In the area of interest, soil samples were taken on a grid pattern at a sampling density of one sample $/ 2 \mathrm{~km}^{2}$. Two soil samples were taken at each site: a 'topsoil' (2531 samples) extending to about 5-20 cm depth, and a 'profile' soil (2697 samples) at $35-50 \mathrm{~cm}$ depth. Stream sediments (1342) and stream waters (1000) were taken from natural first and second-order streams, and were therefore limited to those areas of suitable surface drainage. An average sampling density of only one sample $/ 4 \mathrm{~km}^{2}$ was achieved for stream sediments over the area of interest, this relatively low figure being due to the areas of limestone and chalk outcrop being devoid of low-order surface drainage, and the fenlands where much of the surface drainage is in man-made ditches and drains which do not accurately represent natural surface drainage.
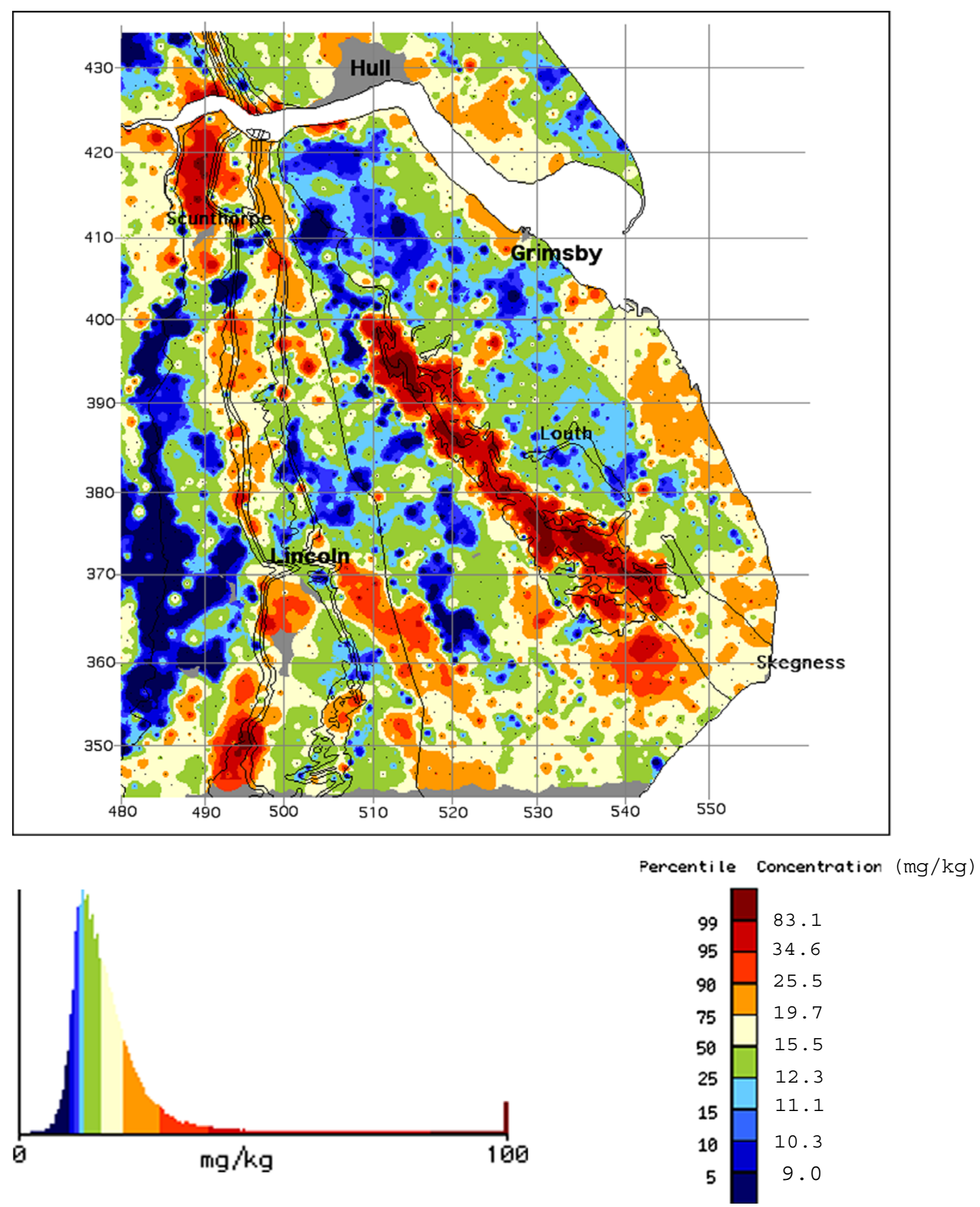

Fig. 5. Arsenic in surface soils, Lincolnshire.1:625,000 geology lines. Gridded at 100 m/pixel. 


\section{Map creation and interpretation}

Regional geochemical data are best presented as thematically coloured maps. These may be produced by a variety of gridding software packages, but those images shown here were generated using a BGS-written bespoke gridding and data analysis module added to the popular NIH-Image image processing programme (Breward and Herd, 1998).
Square-law inverse-distance weighting (IDW) was used as the main gridding algorithm. The coloured, percentile-classified raster files produced were then incorporated into a GIS package such as MapInfo ${ }^{\circledR}$ or ArcView ${ }^{\circledR}$ where further layers of geological and geographical information were added. Extra images such as the multi-component colour-addition maps were produced either in NIH-Image ${ }^{\circledR}$ or in Adobe Photoshop ${ }^{\circledR}$. Each atlas puts the interpretation of
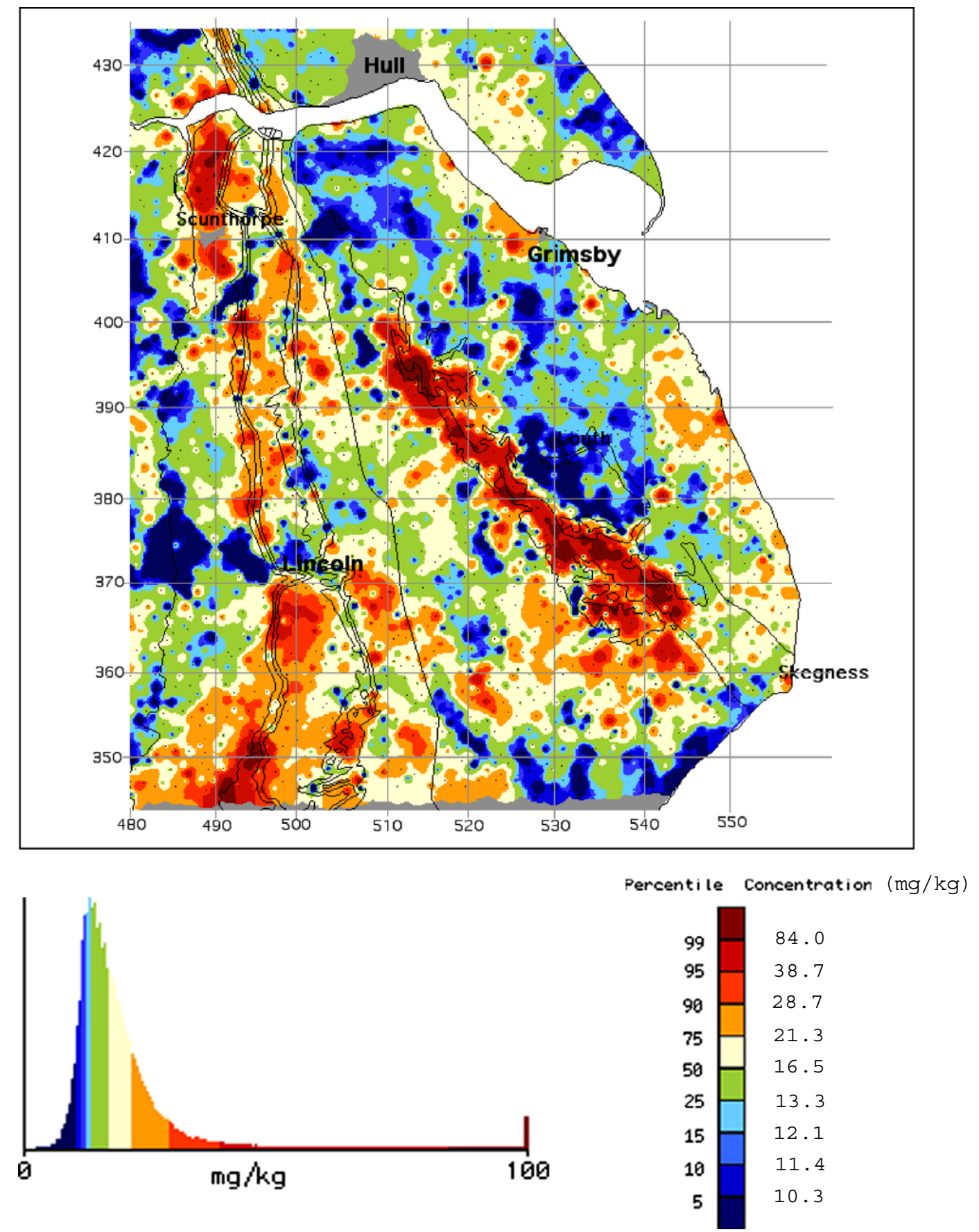

Fig. 6. Arsenic in profile soils, Lincolnshire. 1:625,000 geology lines. Gridded at 100 m/pixel. 
the regional geochemistry in the context of the geology and other available geoscience information such as mineral occurrences. In addition to presenting results in a series of geochemical atlases, G-BASE samples and data are utilised in a wide range of applications and reported in peer-reviewed publications. Recent publications have shown how these regional geochemical data can be used: to interpret subtle geological changes (Stone et al., 2004); to demonstrate the relationships between soils, heavymetal pollution and parent material (Breward, 2003; Rawlins et al., 2002, 2003); in bioacessibility studies (Palumbo-Roe et al., 2005), in archaeology (Chenery et al., 2001); and surface water research (Hutchins et al., 1999).

The geochemical maps shown here display a subset of the regional geochemical data used in the Humber-Trent Regional Geochemical Atlas (British Geological Survey, 2007), re-gridded at a suitable scale (100 m per pixel).

\section{Results and discussion}

\subsection{Arsenic}

The geochemical maps for As in topsoils and profile soils are very similar (Figs. 5 and 6), with the principal ironstone outcrops showing very high As values. Minimum, maximum, mean and median values for As in soils and sediments over each of the major ironstones are given in Table 1.

The tight definition and spatial correlation of the anomalous As levels to the ironstone outcrops indicates both the high levels and the relative lack of dispersion and removal from the soil. Each of the ironstones stands out sharply against the background, but it is of note that the coastal marine alluvium deposits also show moderately high As levels in both soil horizons while the alluvium of the Fens and in the Humberhead Levels show higher levels in the topsoils. The role of Fe oxides in influencing selected trace element concentrations in soils is discussed in Hamon et al., 2004.

Fig. 7 shows As levels in stream sediments, giving a broadly similar distribution pattern to that in the soils, albeit with a rather less continuous coverage due to the lack of natural first-order stream drainage in some areas. High levels are present over the ironstone outcrops, although there are only two stream sediment samples located directly on the Marlstone rock outcrop. The coastal and Humberhead Levels alluvium is less well marked by elevated As levels in the sediments than in the soils, but the anomalies in the Trent valley west of Lincoln are more pronounced.

More significantly, the map for As in stream waters (Fig. 8) shows no sign of elevated dissolved As values over those areas of anomalously high soils and sediment As. This is characteristic of the very high stability of the As-Fe sorption compounds with regards to dissolution and the consequent very slow release and low solubility of As from this source. It would appear that conditions of low $\mathrm{pH}$, low Eh and high soil microbiological activity (giving rise to both reduction and methylation) may be required to mobilise a significant amount of As from these ironstone soils (Alloway, 1995). There is, therefore, very little health or environmental risk from such high As levels in ironstones as the bioaccessibility of the As appears to

Table 1

Minimum, maximum, mean and median values for As in soils and sediments over the ironstone outcrops

\begin{tabular}{|c|c|c|c|c|c|c|c|c|c|c|c|c|}
\hline & \multicolumn{4}{|c|}{ Soil A (surface) } & \multicolumn{4}{|c|}{ Soil S (profile) } & \multicolumn{4}{|c|}{$\underline{\text { Stream sediment }}$} \\
\hline & Min & Max & Mean & Median & Min & Max & Mean & Median & Min & Max & Mean & Median \\
\hline Claxby ironstone & 14 & 342 & $\begin{array}{l}70 \\
n=98\end{array}$ & 50 & 7.6 & 389 & $\begin{array}{l}78 \\
n=93\end{array}$ & 62 & 15.4 & 210 & $\begin{array}{l}70 \\
n=76\end{array}$ & 60.5 \\
\hline Marlstone rock bed & 22 & 146 & $\begin{array}{l}49 \\
n=20\end{array}$ & 33 & 21.2 & 237 & $\begin{array}{l}57 \\
n=26\end{array}$ & 33.8 & 78 & 96 & $\begin{array}{l}87^{\mathrm{a}} \\
n=2\end{array}$ & $\mathrm{n} / \mathrm{a}$ \\
\hline Frodingham ironstone & 25 & 120 & $\begin{array}{l}54 \\
n=31\end{array}$ & 41.5 & 25.0 & 152 & $\begin{array}{l}60 \\
n=28\end{array}$ & 57.6 & 30 & 96 & $\begin{array}{l}65 \\
n=16\end{array}$ & 63 \\
\hline Regional median value & 15.5 & & & & 16.5 & & & & 16.9 & & & \\
\hline
\end{tabular}

All values in $\mathrm{mg} / \mathrm{kg}$.

$n=$ Number of samples.

${ }^{a}$ Not reliable on such a small sample set. 


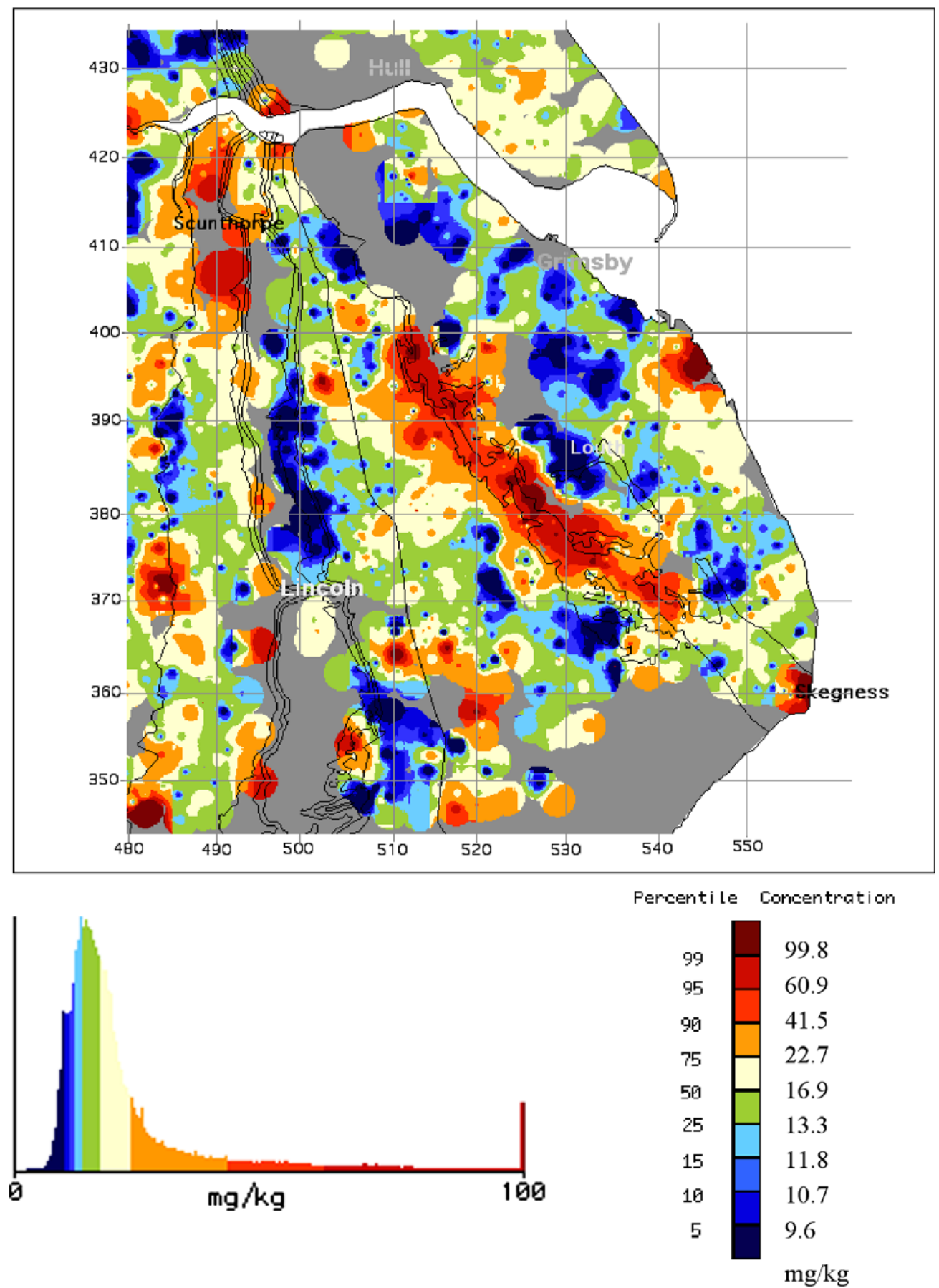

Fig. 7. Arsenic in stream sediments, Lincolnshire. 1:625,000 geology lines. Gridded at $100 \mathrm{~m} /$ pixel.

be extremely low, provided that anoxic, acid weathering conditions do not become established. This is highly unlikely over the main inland outcrops, but may be a cause of the higher As levels noted in stream waters over the coastal sediments e.g., at Somercoates (NGR $\left.{ }^{5} 42,{ }^{3} 97\right), 20 \mathrm{~km} \mathrm{SE}$ of Grimsby.

Geochemical modelling of As speciation and mobility in both the solid phase and pore waters of soils developed over the Frodingham ironstone has been examined by Tye et al., in preparation, using such models as WHAM 6 (Tipping, 1998), and taking into account competition between $\mathrm{AsO}_{4}^{3-}$ and $\mathrm{PO}_{4}^{3-}$. Under the prevailing soil conditions, where total As levels were around $79-145 \mathrm{mg} / \mathrm{kg}$, labile As defined by the 'Olsen P' extract system was found to be have a maximum value of only $0.6 \mathrm{mg} / \mathrm{kg}$ (declining with depth) and soil pore water levels 


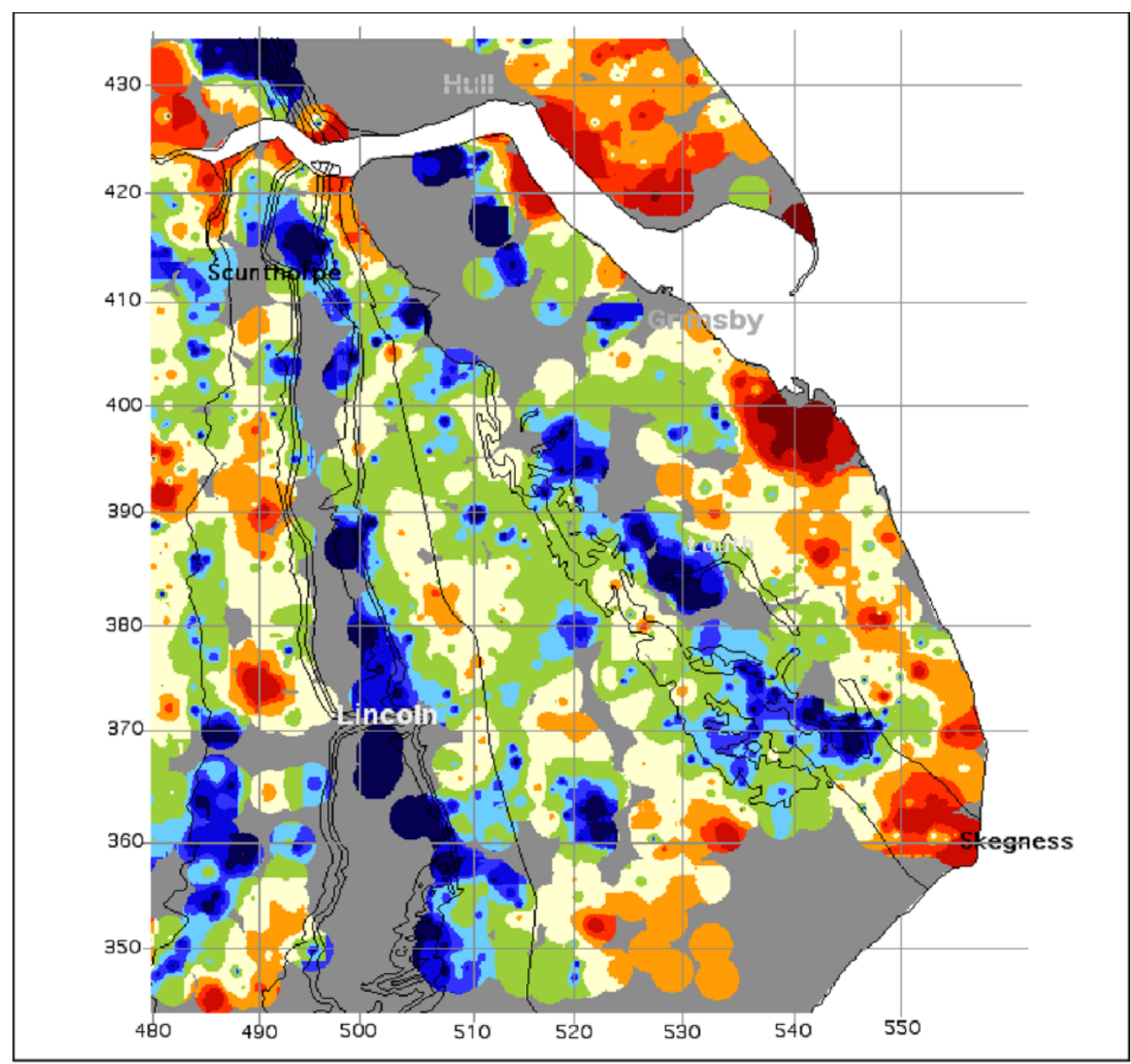

Percentile Concentration
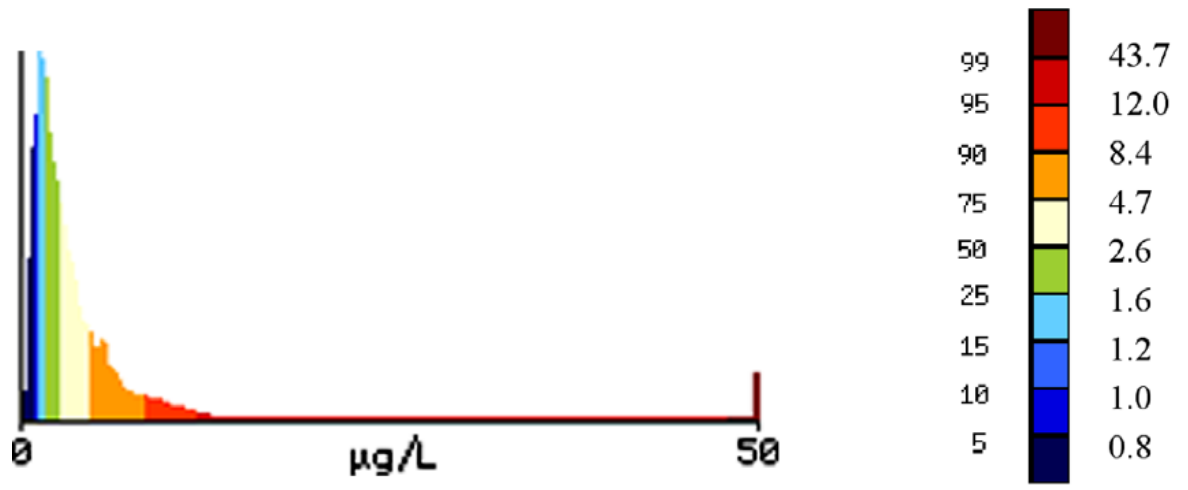

$\mu \mathrm{g} / \mathrm{kg}$

Fig. 8. Arsenic in stream water, Lincolnshire.1:625,000 geology lines. Gridded at $100 \mathrm{~m} /$ pixel.

below $5 \mu \mathrm{g}{ }^{-1}$ throughout the soil profile. The bioaccessibility of As in soils and sediments derived from As-rich ironstones has also been studied using the physiology-based extraction test (PBET) selective extraction test derived by Ruby et al. (1996) and further developed in BGS (Cave et al., 2003). This uses reagents and conditions designed to simulate the solution and sorption characteristics of the human digestive tract. The bioaccessibility of As in the samples has been found to be very low (Palumbo-Roe et al., 2005; Wragg, 2005), using both PBET and other sequential-extraction and chemometric methods. These showed that the bulk of the As was held in less reactive, low-solubility $\mathrm{Fe}$ phases, thus reinforcing 
the observation that very little As is moving in solution into the stream waters.

This clearly has implications for the treatment of 'contaminated' land. Many of the soils in these areas have total As levels well above the soil guideline values derived by the CLEA model of $30 \mathrm{mg} / \mathrm{kg}$ for residential areas (DEFRA, 2002) and would require 'remediation' in the event of development, even though the high levels are entirely natural and the As is almost completely immobile and non-bioaccessible under normal surface conditions. The current legislation, based solely on 'total' element analyses of soils, would therefore appear to be seriously flawed in this aspect, and refinements to these models (and the legislation based on them) to take the bioaccessibility of the 'contaminant' into account, are recommended.

The high levels of As in the Claxby soils and sediments compared to those derived from the other ironstone outcrops are also worthy of note. The ironstones of the Wealden district in southern England, which are similar in age to the Claxby ironstone, do not show particularly high As levels (J D Appleton, BGS, pers. comm.) so this is not a general feature of the Lower Cretaceous and a more local sedimentation effect must be responsible. In the Wealden district, the Lower Cretaceous sedimentation follows the latest Jurassic shallowwater marine sediments without a break, the only significant unconformity within the Lower Cretaceous being above the horizon of the ironstones. However, in Lincolnshire the base of the Cretaceous (the base of the Spilsby Sandstone is actually of uppermost Jurassic age, but this does not affect the case proposed) is transgressive westwards over an uplifted late-Jurassic land surface, and exposed Oxford Clay and Kimmeridge Clay would have provided a source of sediment to the Lower Cretaceous sea, the coastline of which was probably not more than a few $\mathrm{km}$ west of the current outcrop (Rawson, 1992). Both clay formations are relatively rich in $\mathrm{S}$ and organic matter and thus might provide a richer source of As and other elements to the lagoonal ironstone depositional system. Subaerial weathering of these

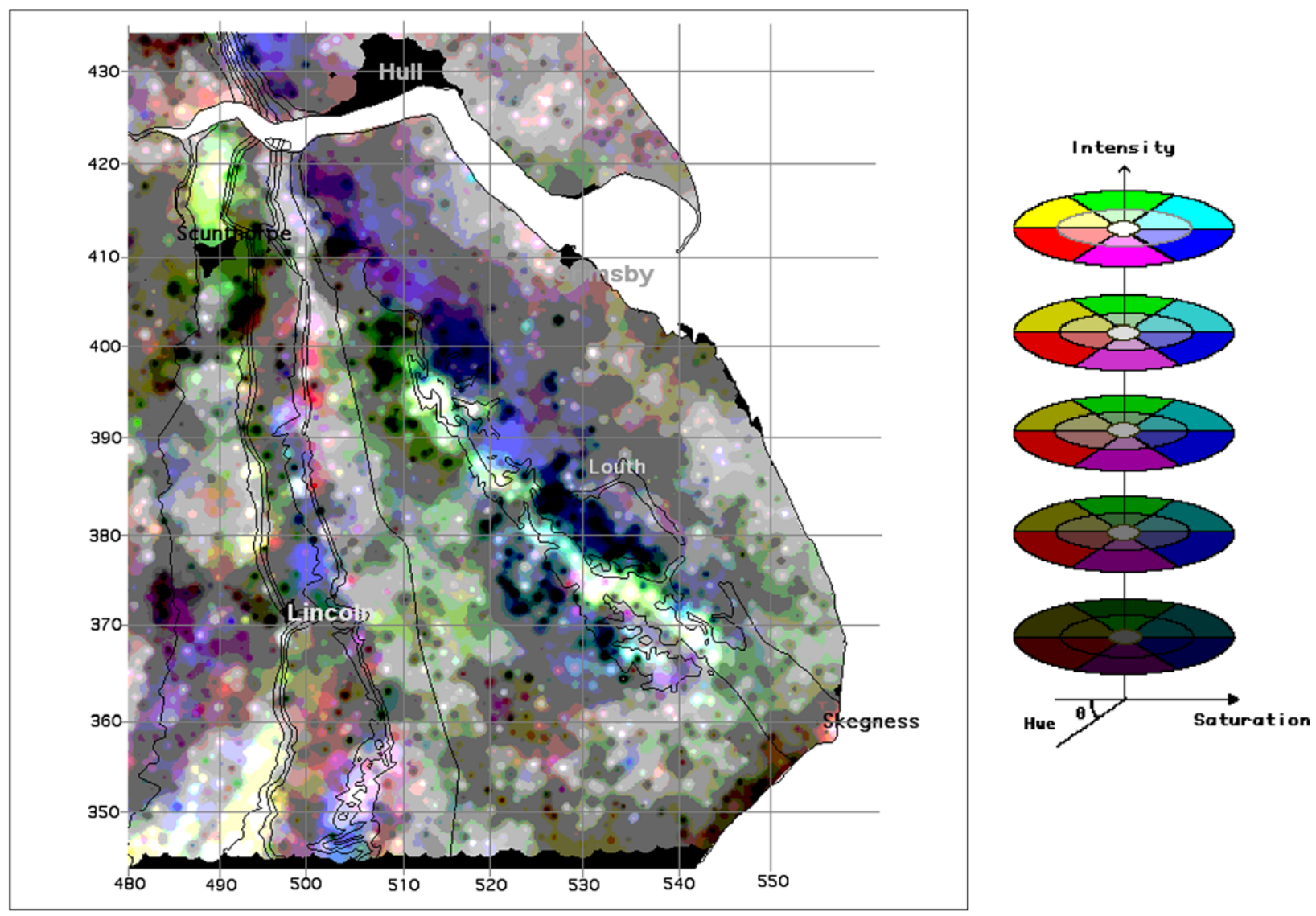

Fig. 9. Profile soil chromium (red), vanadium (green) and lanthanum (blue) RGB addition map. 1:625,000 geology lines. 
formations might also have yielded the low-pH stream conditions required for the transport of $\mathrm{Fe}^{2+}$ in solution.

\subsection{Other elements}

Arsenic is not the only trace element commonly observed to be enriched in soils and sediments derived from sedimentary ironstones, and this is certainly true of those in the study area. A threecomponent RGB map (red-green-blue colouraddition map, see Breward, 2003) for profile soil $\mathrm{Cr}, \mathrm{V}$ and La is shown as an illustration (Fig. 9). The major ironstone units are picked out clearly as bright near-white areas (indicating high levels of all three elements), especially the Claxby ironstone outcrop which is very sharply defined. More diffuse areas of moderately high values of supposed 'resistate' elements are shown in mid-grey by the coastal marine alluvium, the Fen soils west of
Skegness, parts of the Trent floodplain and the superficial deposits over the low-lying Upper Jurassic clay outcrop to the east of the Lincolnshire Limestone ridge.

These trace elements may occur at elevated levels in ironstones either through chemical concentration (like As) or from the residual detrital fraction. The latter tends to be enriched in heavy, resistate minerals and their associated elements, such as $\mathrm{V}, \mathrm{Cr}, \mathrm{Ce}$, $\mathrm{La}$ and Th minerals such as magnetite, chrome-spinel and monazite are suggested by this enriched element suite. However, $\mathrm{TiO}_{2}$ levels are unremarkable over the ironstones and $\mathrm{Zr}$ levels are notably low (both typically resistate elements) and maps for these are not given, so the observed patterns are unlikely to be caused simply by a generalised resistate mineral assemblage. Table 2 shows maximum, minimum, mean and median values for $\mathrm{V}, \mathrm{Cr} \mathrm{La}, \mathrm{Ce}$ and $\mathrm{Th}$ in soils and sediments over the ironstones, and the regional median for these elements, in order

Table 2

Maximum, minimum, mean and median values for $\mathrm{V}, \mathrm{Cr}, \mathrm{La}, \mathrm{Ce}$ and $\mathrm{Th}$ in soils and sediments over the ironstone outcrops

\begin{tabular}{|c|c|c|c|c|c|c|c|c|c|c|c|c|c|}
\hline & & \multicolumn{4}{|c|}{ Soil A (surface) } & \multicolumn{4}{|c|}{ Soil S (profile) } & \multicolumn{4}{|c|}{ Stream sediment } \\
\hline & & Min & Max & Mean & Median & Min & Max & Mean & Median & Min & Max & Mean & Median \\
\hline \multirow[t]{6}{*}{ Claxby ironstone } & $\mathrm{V}$ & 34 & 831 & 201 & 152 & 31 & 1013 & 204 & 152 & 41 & 390 & 177 & 165 \\
\hline & $\mathrm{Cr}$ & 16 & 254 & 100 & 87 & 12 & 280 & 108 & 100 & 16 & 175 & 111 & 110 \\
\hline & $\mathrm{La}$ & $\mathrm{n} / \mathrm{a}$ & & & & 11 & 121 & 53.6 & 53.6 & 23 & 108 & 46.7 & 45 \\
\hline & $\mathrm{Ce}$ & $\mathrm{n} / \mathrm{a}$ & & & & 15 & 283 & 112.4 & 102 & 44 & 205 & 98.2 & 96 \\
\hline & $\mathrm{Th}$ & $\mathrm{n} / \mathrm{a}$ & & & & 1.8 & 26.1 & 9.8 & 9.3 & 3.0 & 15.4 & 9.4 & 9.2 \\
\hline & Samples & $n=9$ & & & & $n=9$ & & & & $n=7$ & & & \\
\hline \multirow[t]{6}{*}{ Marlstone Rock Bed } & $\mathrm{V}$ & 119 & 462 & 223 & 179 & 107 & 589 & 234 & 194.5 & 137 & 280 & $208^{\mathrm{a}}$ & $\mathrm{n} / \mathrm{a}$ \\
\hline & $\mathrm{Cr}$ & 86 & 289 & 141 & 117 & 82 & 394 & 159 & 131.5 & 87 & 201 & $144^{\mathrm{a}}$ & $\mathrm{n} / \mathrm{a}$ \\
\hline & $\mathrm{La}$ & $\mathrm{n} / \mathrm{a}$ & & & & 34 & 81 & 54.7 & 53.5 & 49 & 54 & $51.5^{\mathrm{a}}$ & $\mathrm{n} / \mathrm{a}$ \\
\hline & $\mathrm{Ce}$ & $\mathrm{n} / \mathrm{a}$ & & & & 74 & 188 & 124.8 & 117 & 112 & 131 & $121.5^{\mathrm{a}}$ & $\mathrm{n} / \mathrm{a}$ \\
\hline & $\mathrm{Th}$ & $\mathrm{n} / \mathrm{a}$ & & & & 7.6 & 27.9 & 13.6 & 12.3 & 8.6 & 14.9 & $11.7^{\mathrm{a}}$ & $\mathrm{n} / \mathrm{a}$ \\
\hline & Samples & $n=2$ & & & & $n=2$ & & & & $n=2$ & & & \\
\hline \multirow[t]{6}{*}{ Frodingham ironstone } & $\mathrm{V}$ & 79 & 534 & 197 & 152 & 107 & 985 & 243 & 185 & 54 & 338 & 223 & 213 \\
\hline & $\mathrm{Cr}$ & 39 & 250 & 100 & 90.5 & 53 & 241 & 123 & 112.5 & 52 & 275 & 129 & 130 \\
\hline & $\mathrm{La}$ & $\mathrm{n} / \mathrm{a}$ & & & & 23 & 85 & 46.9 & 46.0 & 23 & 72 & 50.1 & 50.0 \\
\hline & $\mathrm{Ce}$ & $\mathrm{n} / \mathrm{a}$ & & & & 54 & 279 & 109 & 101.5 & 46 & 152 & 110.9 & 116 \\
\hline & $\mathrm{Th}$ & $\mathrm{n} / \mathrm{a}$ & & & & & 57.2 & 15.1 & 12.8 & 3.4 & 25.4 & 15.3 & 14.7 \\
\hline & Samples & $n=3$ & & & & $n=2$ & & & & $n=1$ & & & \\
\hline \multirow[t]{6}{*}{ Regional median value } & $\mathrm{V}$ & 83 & & & & 88 & & & & 100 & & & \\
\hline & $\mathrm{Cr}$ & 71 & & & & 83 & & & & 95 & & & \\
\hline & $\mathrm{La}$ & $\mathrm{n} / \mathrm{a}$ & & & & 40.1 & & & & 39.3 & & & \\
\hline & $\mathrm{Ce}$ & $\mathrm{n} / \mathrm{a}$ & & & & 82.0 & & & & 81.5 & & & \\
\hline & $\mathrm{Th}$ & $\mathrm{n} / \mathrm{a}$ & & & & 8.3 & & & & 8.2 & & & \\
\hline & Samples & $n=2$ & & & & $n=2$ & & & & $n=1$ & 342 & & \\
\hline
\end{tabular}

All values in $\mathrm{mg} / \mathrm{kg}$.

$n=$ Number of samples.

${ }^{a}$ Not reliable on such a small sample set. 


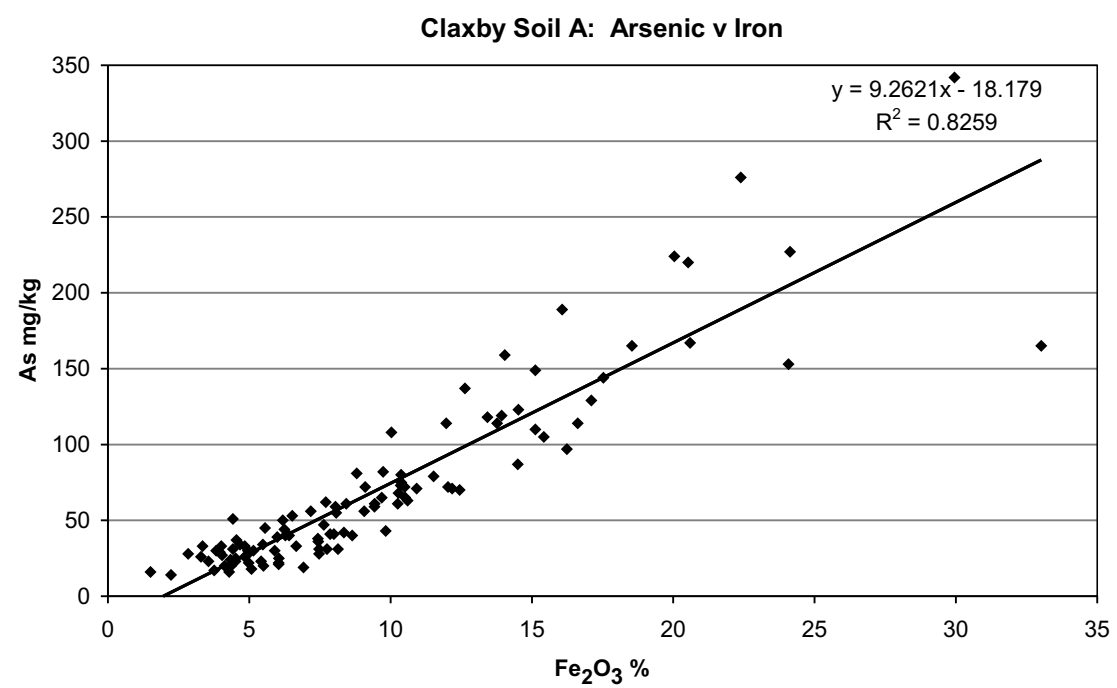

Claxby Soil S: Arsenic v Iron
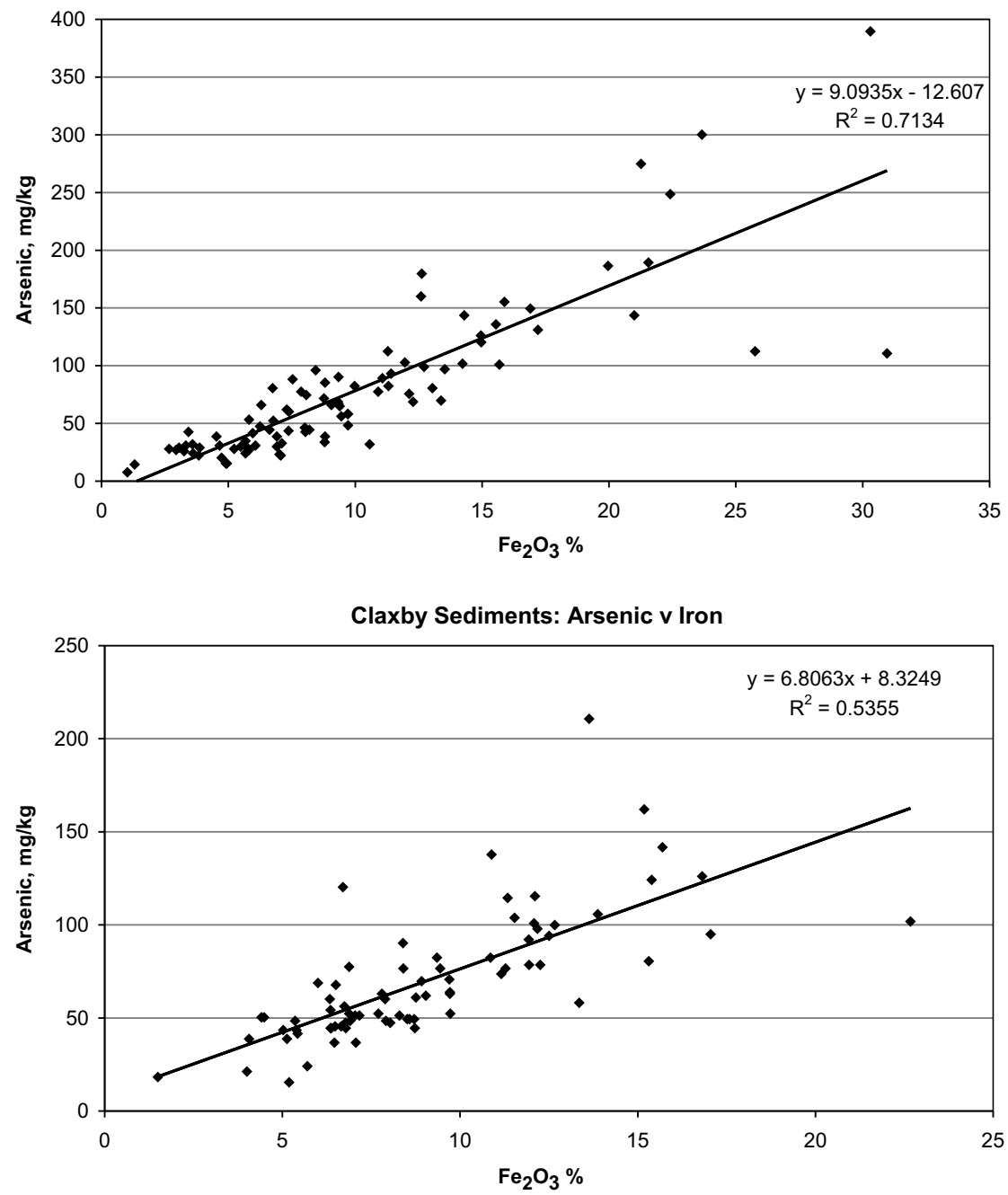

Fig. 10. Correlation graphs for arsenic against iron $\left(\mathrm{Fe}_{2} \mathrm{O}_{3}\right)$ content in soils $(\mathrm{A}=$ surface, $\mathrm{S}=$ profile $)$ and stream sediments.

to allow comparison with those of As from Table 1. Note that $\mathrm{La}, \mathrm{Ce}$ and $\mathrm{Th}$ data are not available for the topsoils.
In Figs. 10-12, the scatter-plots and correlation of As, $\mathrm{V}$ and $\mathrm{P}$ against $\mathrm{Fe}$ for soils and sediments derived from the ironstones reveal a number of 

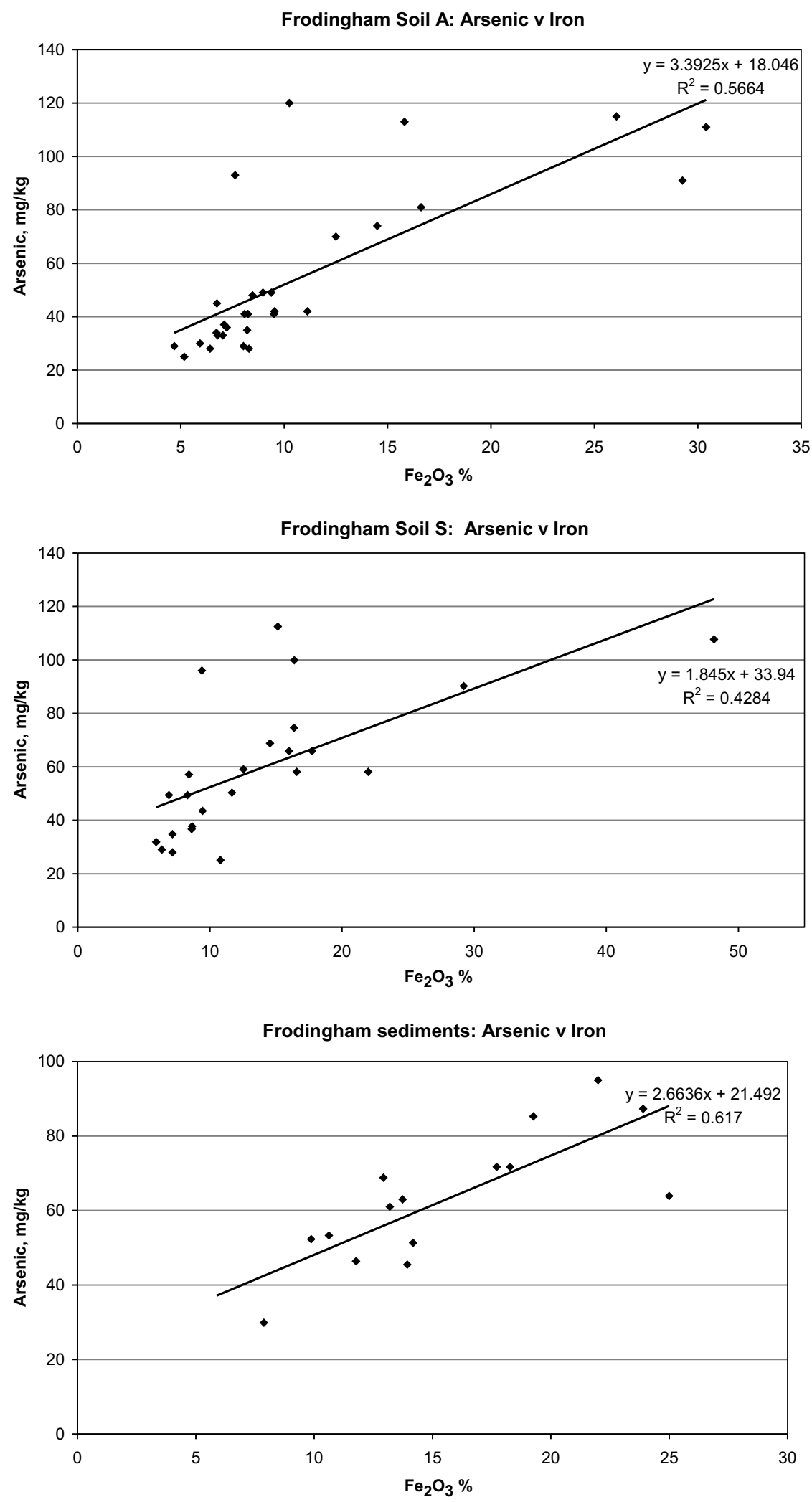

Fig. 10 (continued)

curious features. Very strong correlations between $\mathrm{Fe}$ and As are shown by both soil horizons and stream sediments for the Claxby ironstone outcrop, though with more scatter for the sediments, perhaps indicating some limited mobility and redistribution on weathering. Both soil horizons show strong 

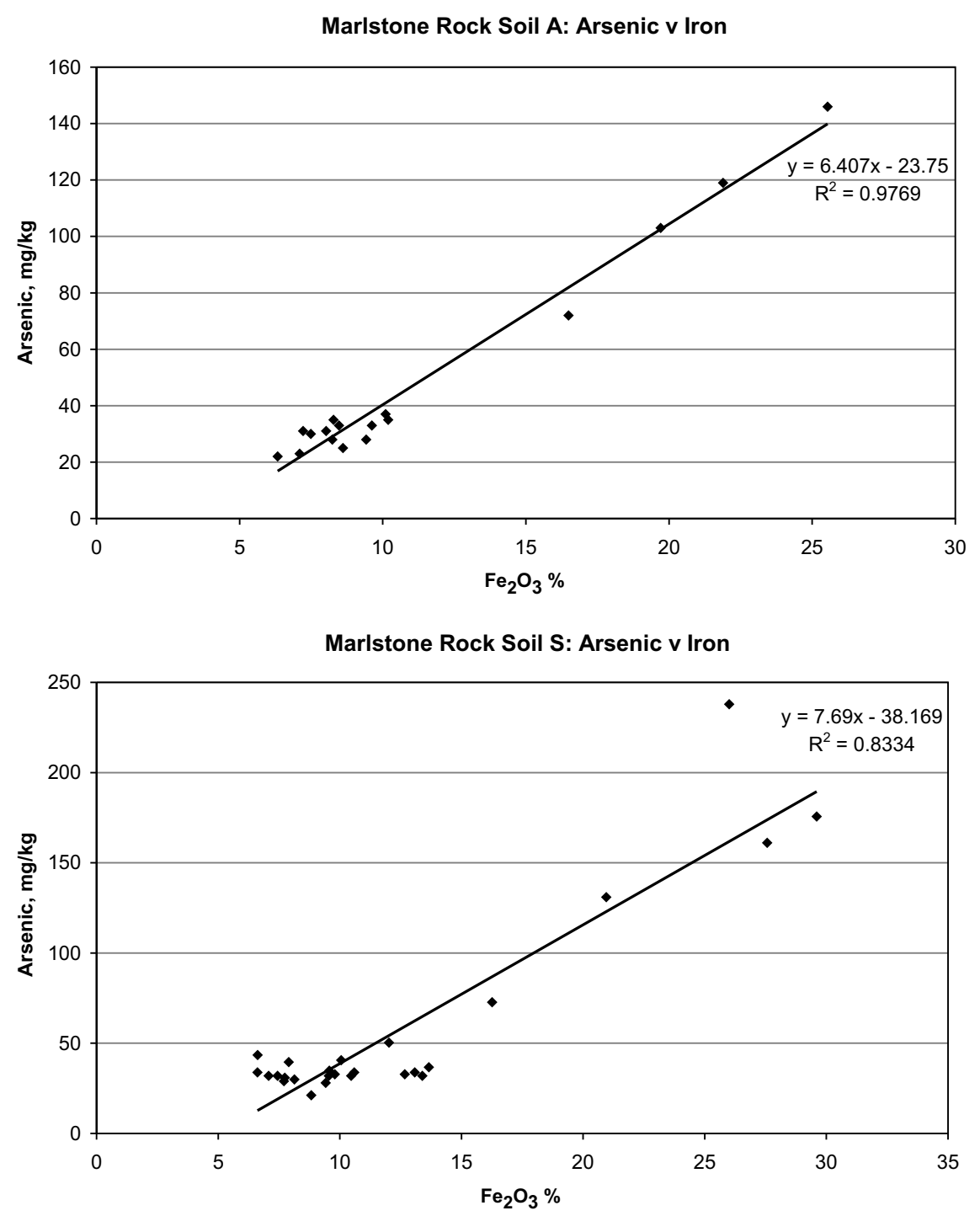

Fig. 10 (continued)

$\mathrm{Fe}-\mathrm{As}$ links over the Marlstone rock bed, though on many fewer samples, but it may be significant that weaker correlation is shown by the Frodingham soils and sediments, although the trends are similar but of lower slope and overall As levels. This suggests that the Frodingham soils are more disturbed and contaminated by outfall from the local iron and steel industry, possibly by Fe-rich dusts from which the As has been removed, which weakens the direct geogenic correlation.

The patterns shown by $\mathrm{V}$ are broadly similar to those given by As, again giving very strong correlations, but the sediments derived from the Frodingham ironstone show a breakdown in correlation at high Fe levels, though this is based on only two aberrant samples and otherwise the correlation is strongly positive, similar to that in the soils. Whether this is again a feature of the industrial overprint of the Scunthorpe area on the Frodingham samples is not clear. It is likely, given this strong correlation, that the enriched levels of $\mathrm{V}$ are, at least in part, due to in situ sorption and concentration by the sedimentary $\mathrm{Fe}$ oxides during their formation. This is probably related to the geochemical similarity of the $\mathrm{VO}_{4}^{3-}$ anion and its derivatives such as $\mathrm{HVO}_{4}^{2-}$ and $\mathrm{H}_{2} \mathrm{VO}_{4}^{-}$with those of $\mathrm{AsO}_{4}^{3-}$ and $\mathrm{PO}_{4}^{3-}$ (Brookins, 1988 ) and the possibility of formation of a $\mathrm{Fe}^{\mathrm{III}}$ vanadate complex replacement mineral related to the strengite-scorodite group. Leaching of Frodingham ironstone soil samples by increasing strengths of $\mathrm{HCl}$ has been carried out at BGS for another project (M R Cave, BGS; pers. comm.) and also suggests that 
Claxby Soil A: Vanadium v Iron

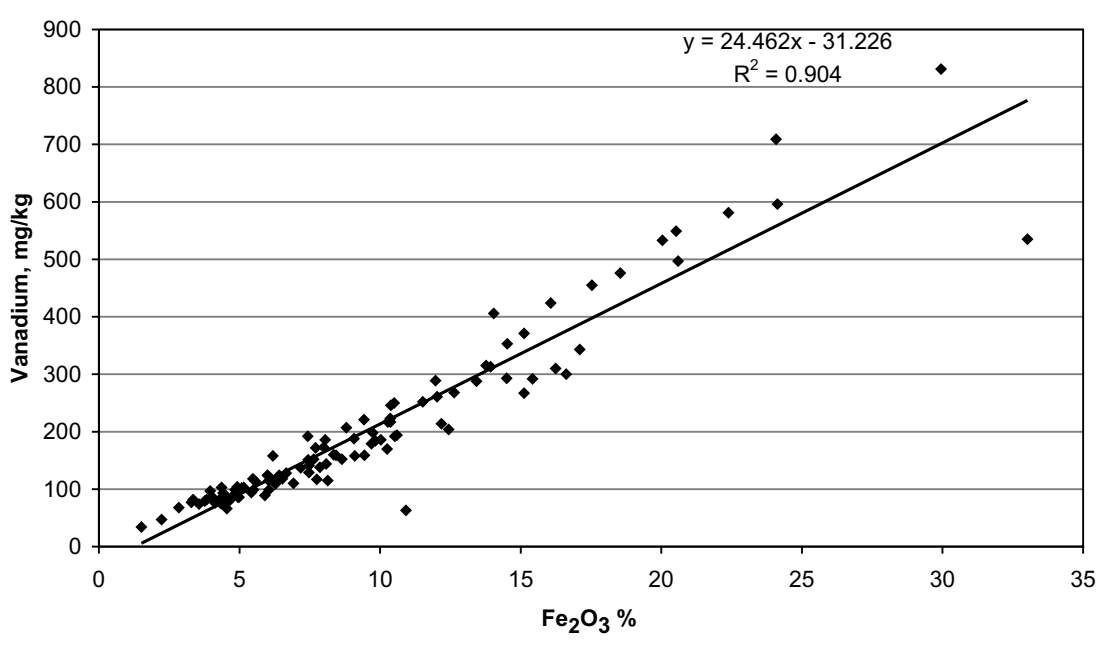

Claxby Soil S: Vanadium v Iron

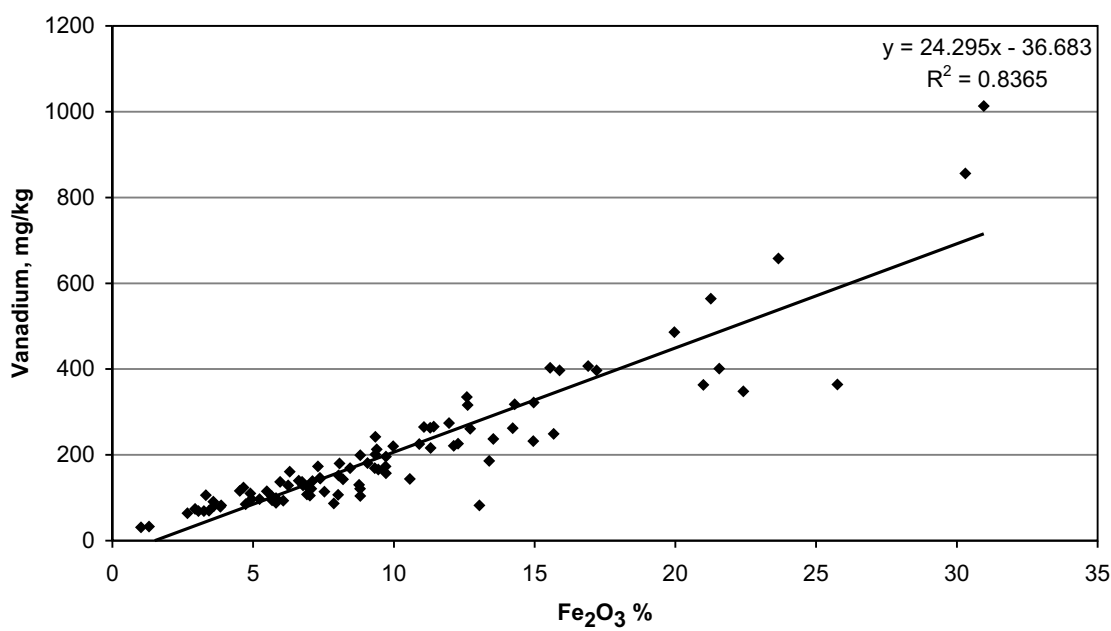

Claxby Sediments: Vanadium v Iron

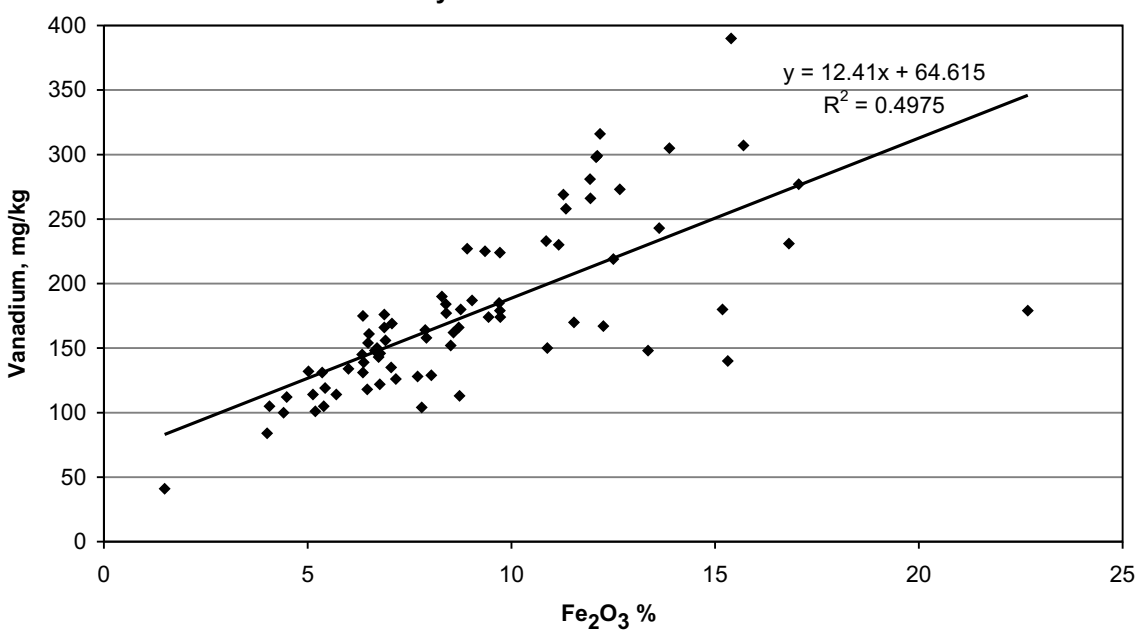

Fig. 11. Correlation graphs for vanadium against iron $\left(\mathrm{Fe}_{2} \mathrm{O}_{3}\right)$ content in soils $(\mathrm{A}=$ surface, $\mathrm{S}=$ profile $)$ and stream sediments.

a sedimentary oxide phase, rather than resistate oxides or silicates, is the host for most of the $\mathrm{V}$ in these soils. Vanadium levels in stream waters over the iron- stones are not elevated, despite the high $\mathrm{V}$ levels in soils and sediments, so the environmental mobility of the sorbed $\mathrm{V}$ is clearly low, as is the case for As and $\mathrm{PO}_{4}^{3-}$. 
Frodingham Soil A: Vanadium v Iron

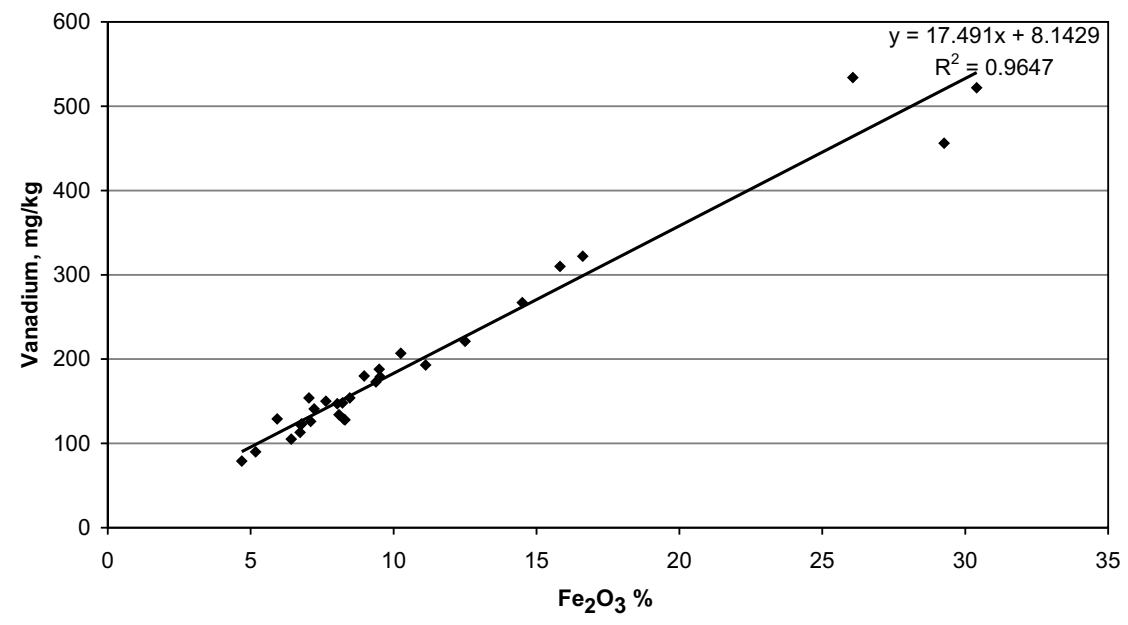

Frodingham Soil S: Vanadium v Iron

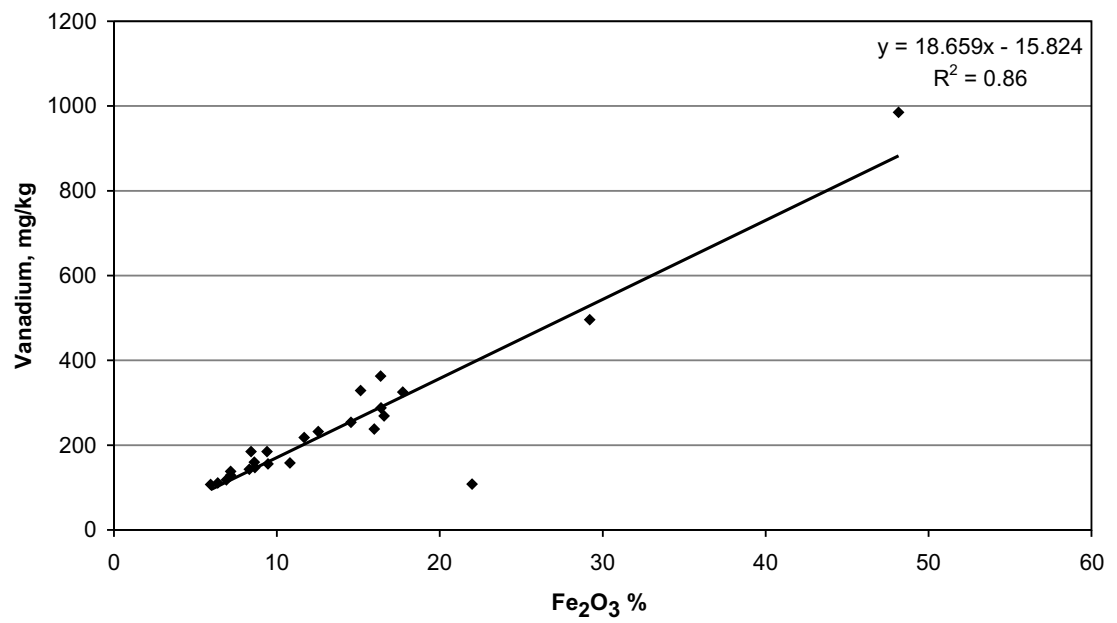

Frodingham Sediments: Vanadium v Iron

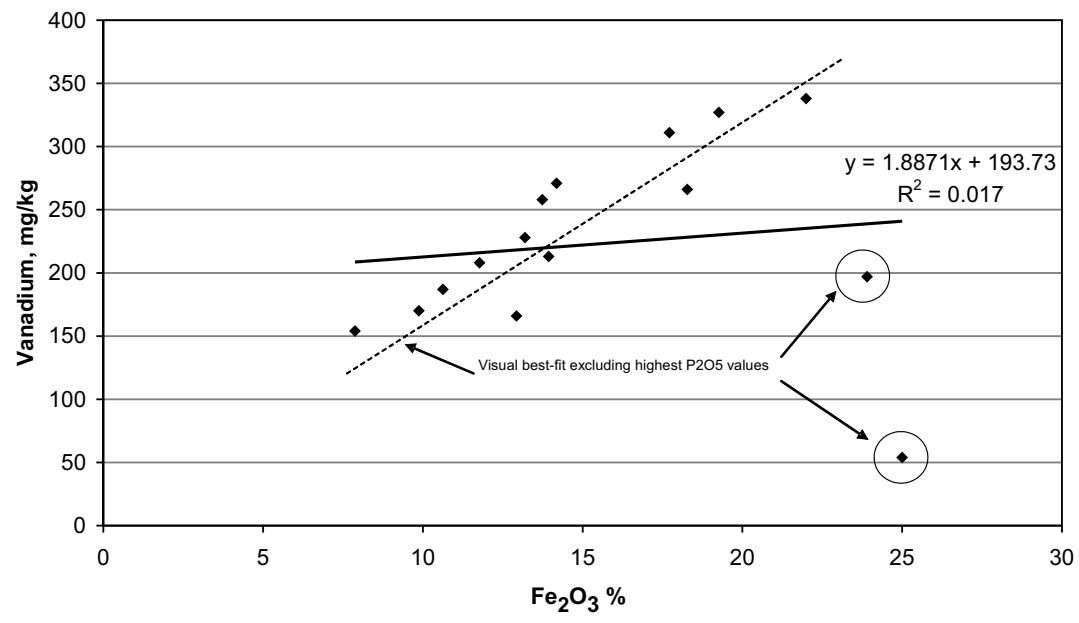

Fig. 11 (continued)

Less expected, given the commonly observed association between sedimentary $\mathrm{Fe}$ oxides and $\mathrm{PO}_{4}^{3-}$, is the very poor correlation shown by $\mathrm{P}$ and $\mathrm{Fe}$ in the Claxby soils and sediments. Positive, though not especially strong, correlations are present with both the Frodingham and Marlstone rock 

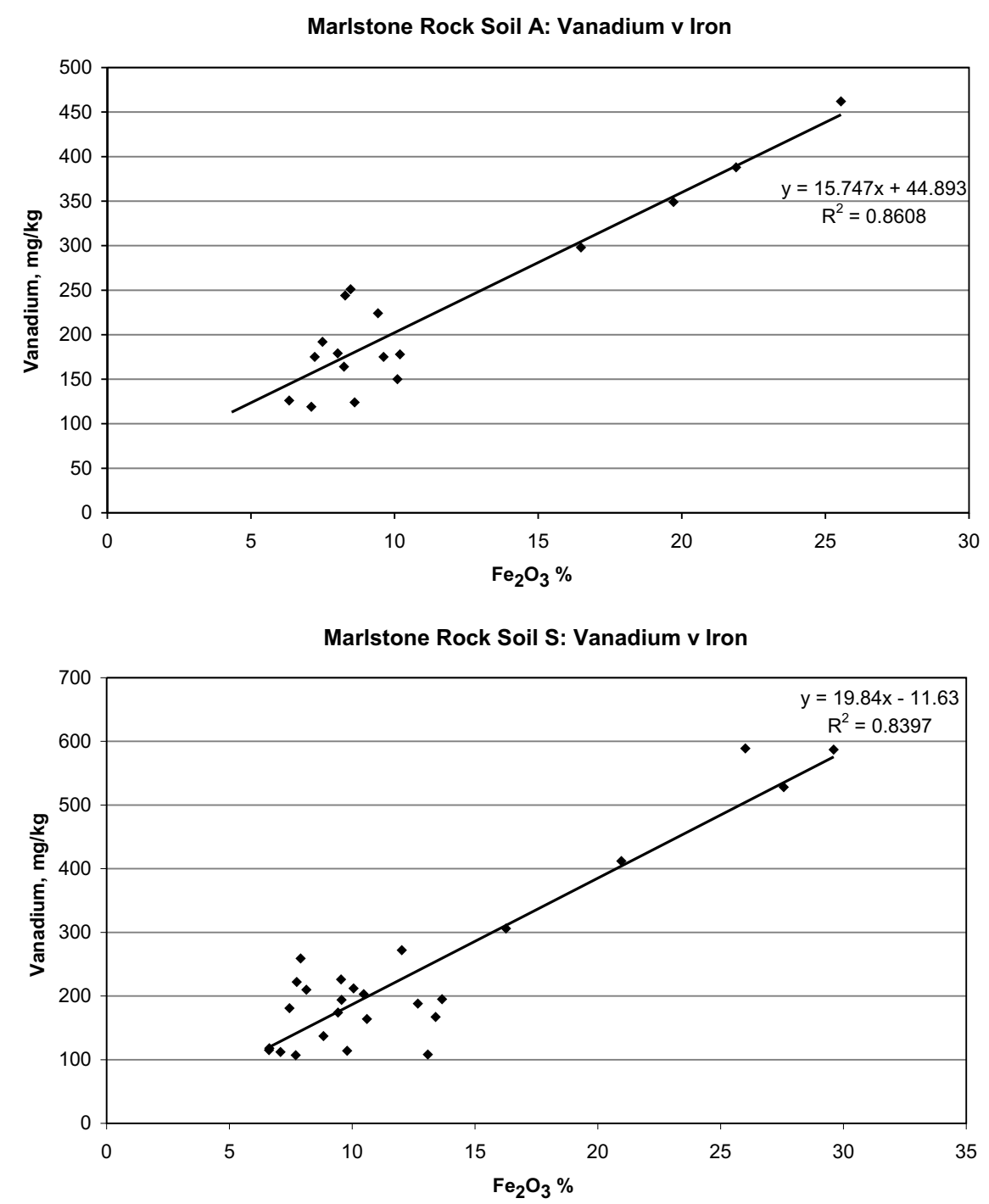

Fig. 11 (continued)

soils, but not the Frodingham sediments. The Claxby pattern clearly suggests a non-Fe oxide source for the $\mathrm{P}$, and the lack of a strong correlation with any other major soil or sediment component suggests an independent input source, possibly of agricultural fertiliser, though this is far from conclusive. However, a strong correlation $\left(r^{2}=0.66\right.$ for $>990$ samples) between $\mathrm{PO}_{4}^{3-}$ and $\mathrm{NO}_{3}^{-}$in stream waters throughout Lincolnshire is typical of such an intensively farmed county with high inputs of fertilisers. Quite why this should have more of an impact on the soils over the Claxby ironstone rather than the other geological units is uncertain. The presence of the overlying Chalk outcrop might be a factor, but there is not a strong $\mathrm{Ca}-\mathrm{P}$ correlation in the soils either, which may negate this explanation.
The elevated levels of $\mathrm{Cr}, \mathrm{Ce}, \mathrm{La}$ and $\mathrm{Th}$ were, according to their conventionally-understood geochemical behaviour, expected to have a predominantly resistate mineral source. However, fairly strong positive correlations for these elements with $\mathrm{Fe}$ have been observed in profile soils over the ironstones (Fig. 13), with $\mathrm{Cr}$ and $\mathrm{Ce}$ showing the strongest enrichments. It seems unlikely that the geochemical conditions required for ironstone formation would also allow the mobilisation and concentration of all of these elements by a similar process of sorption or co-precipitation, nor should normal temperate soil processes generate such a correlation as an artefact, yet this suggests that processes other than simple resistate heavy-mineral concentration are operating. Although $\mathrm{Fe}^{2+}, \mathrm{Cr}^{3+}$ 

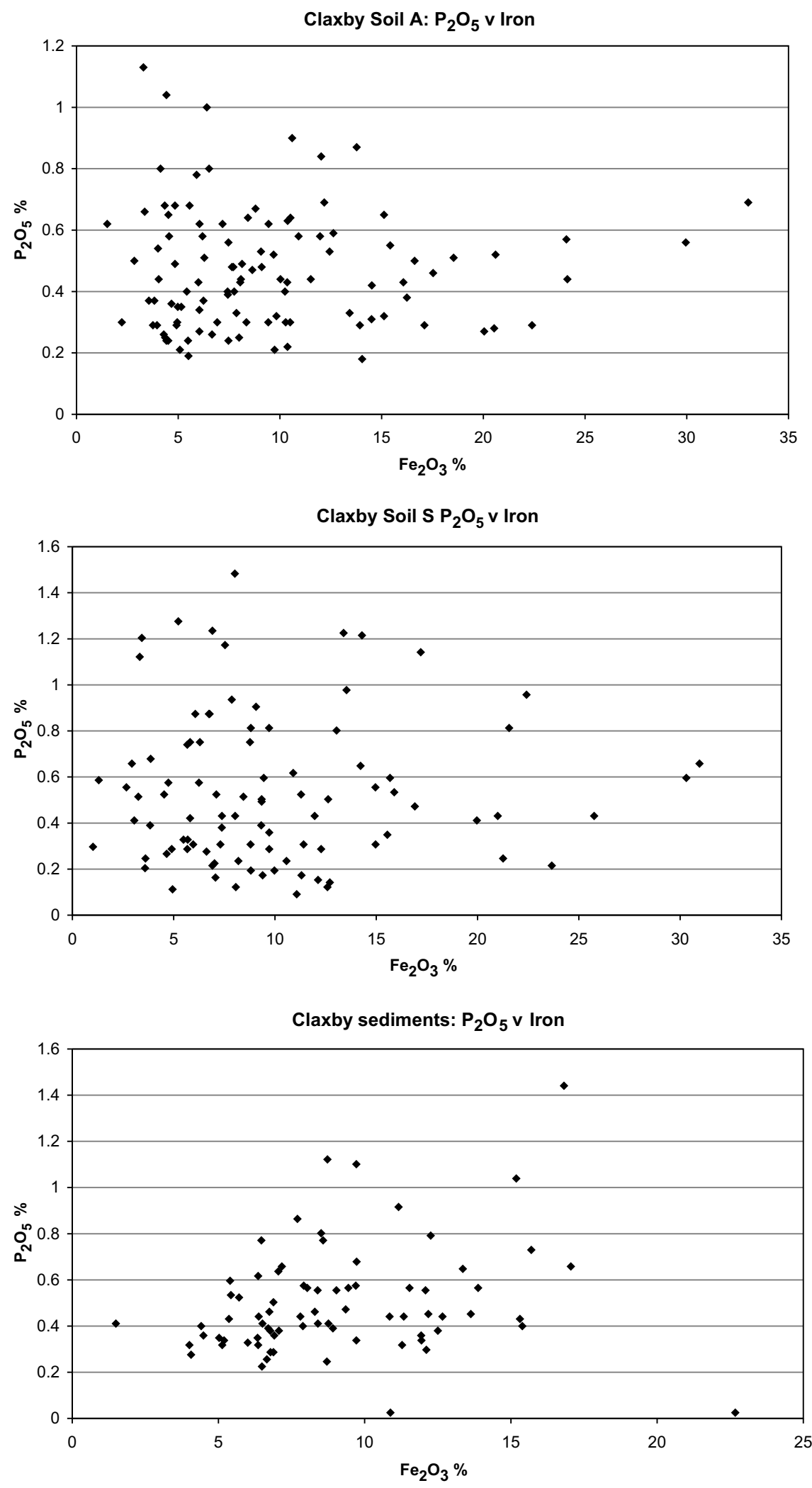

Fig. 12. Correlation graphs for phosphorus $\left(\mathrm{P}_{2} \mathrm{O}_{5}\right)$ against iron $\left(\mathrm{Fe}_{2} \mathrm{O}_{3}\right)$ content in soils $(\mathrm{A}=$ surface, $\mathrm{S}=$ profile $)$ and stream sediments.

and $\mathrm{VO}^{2+}$ can co-exist in solution at $\mathrm{pH}$ values $<4.0$ and then be taken up by coprecipitation of hydrous $\mathrm{Fe}^{(\mathrm{III})}$ oxide (Brookins, 1988), is it pos- sible that small amounts of $\mathrm{La}^{3+}$ and $\mathrm{Ce}^{3+}$ may also be initially mobilised then similarly co-precipitated with the $\mathrm{Fe}$ oxides? Can this also be 

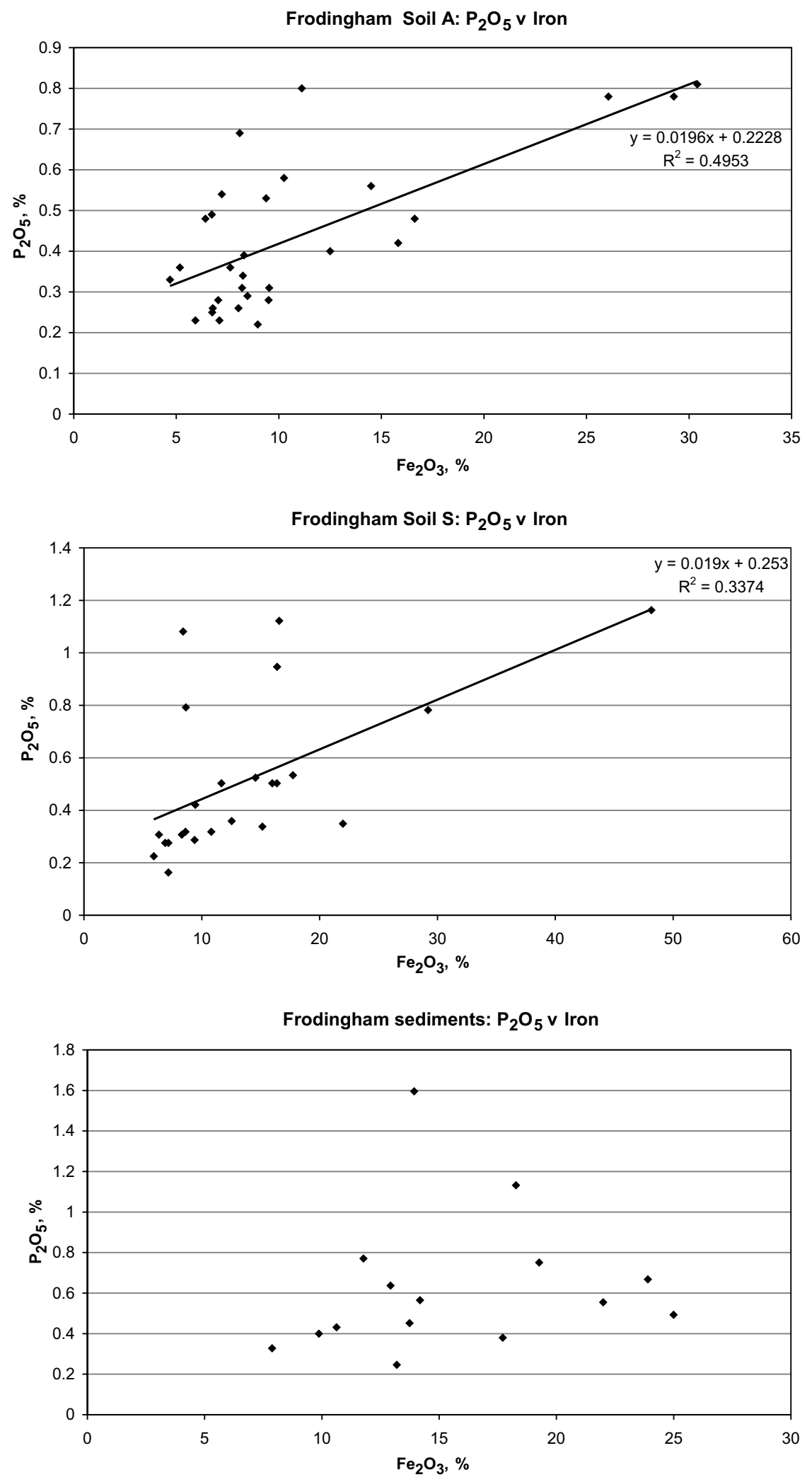

Fig. 12 (continued)

true for Th to a more limited extent? Although not so strongly enriched as the other elements, Th shows one of the strongest positive correla- tions with $\mathrm{Fe}_{2} \mathrm{O}_{3}$, which does suggest that a 'real' causative process is operating and that this is not merely a coincidence. 
Marlstone Soil A: $\mathrm{P}_{2} \mathrm{O}_{5} \mathrm{v}$ Iron

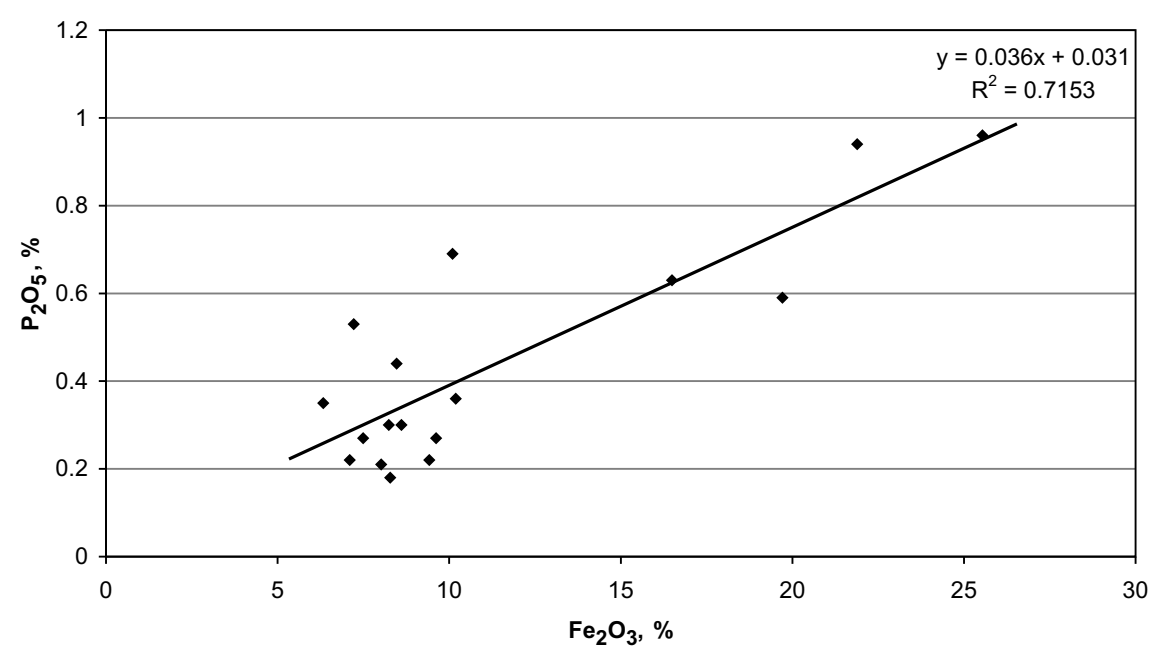

Marlstone Rock Soil S: $\mathrm{P}_{\mathbf{2}} \mathrm{O}_{5} \mathrm{v}$ Iron

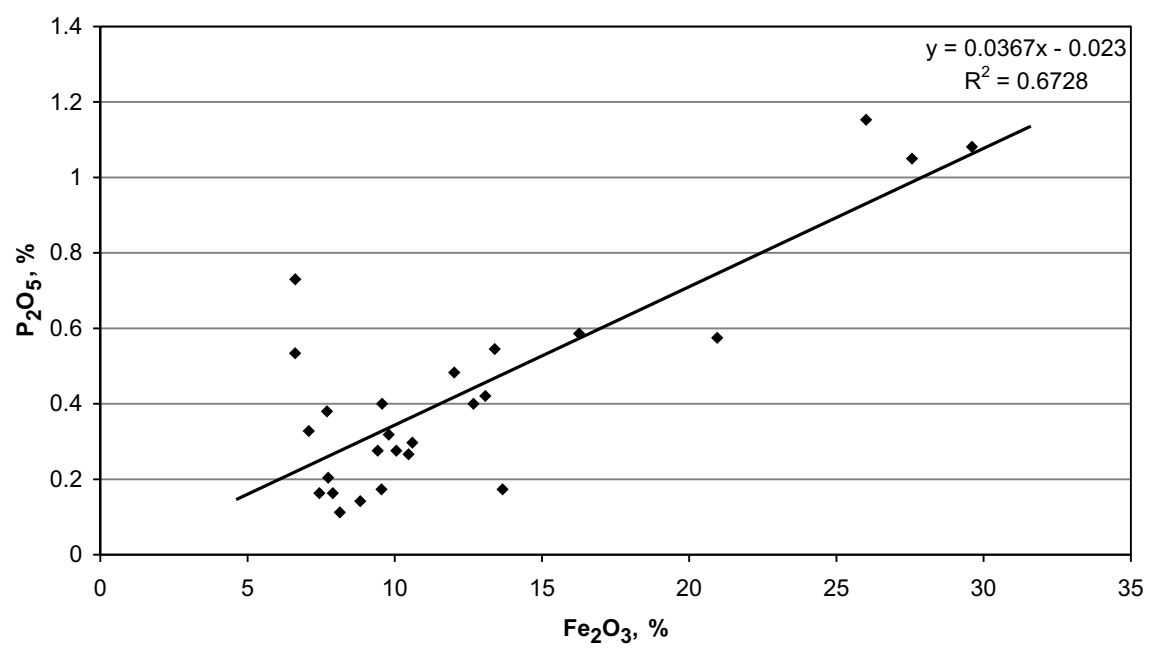

Fig. 12 (continued)

When such unexpected observations are made, it is tempting to suggest that analytical artefacts such as positive interferences of the very high $\mathrm{Fe}$ levels on the trace elements during the X-ray fluorescence analyses - may be responsible, but careful re-analysis of a subset of samples by XRF and examination of the data suggests that this is not responsible. The evidence shown by this data therefore, although limited and not conclusive, would suggest that the contemporaneous mobilisation and transport of these 'resistate' elements, followed by sorption by the Fe oxides, was a viable natural geochemical process. There is still much to learn about the environmental chemistry of low-mobility elements such as Th, and modern analytical techniques such as ICP-MS are rendering the concept of an 'insoluble' element obsolete by, for example, providing credible regional stream-water data for $\mathrm{Th}$ and $\mathrm{Zr}$ at a detection limit of less than $0.01 \mu \mathrm{g} /$ 1. Correlations, of course, are not always causative, and reliance on simple thermodynamic Eh-pH diagrams may be misleading, but this phenomenon is worthy of further investigation. Other heavy metals, such as $\mathrm{Ni}, \mathrm{Co}, \mathrm{Cu}$ and $\mathrm{Pb}$, do not show this linkage.

\section{Summary and conclusions}

The Lincolnshire ironstones give rise to high levels of As and some other trace elements in soils and stream sediments. However, the stability of the Fe oxides is such that As mobility and bioaccessibility at least is extremely low, and there is no As elevation in the associated stream waters. Although the 
Claxby Profile Soil: La, Ce, Cr, Th v Iron

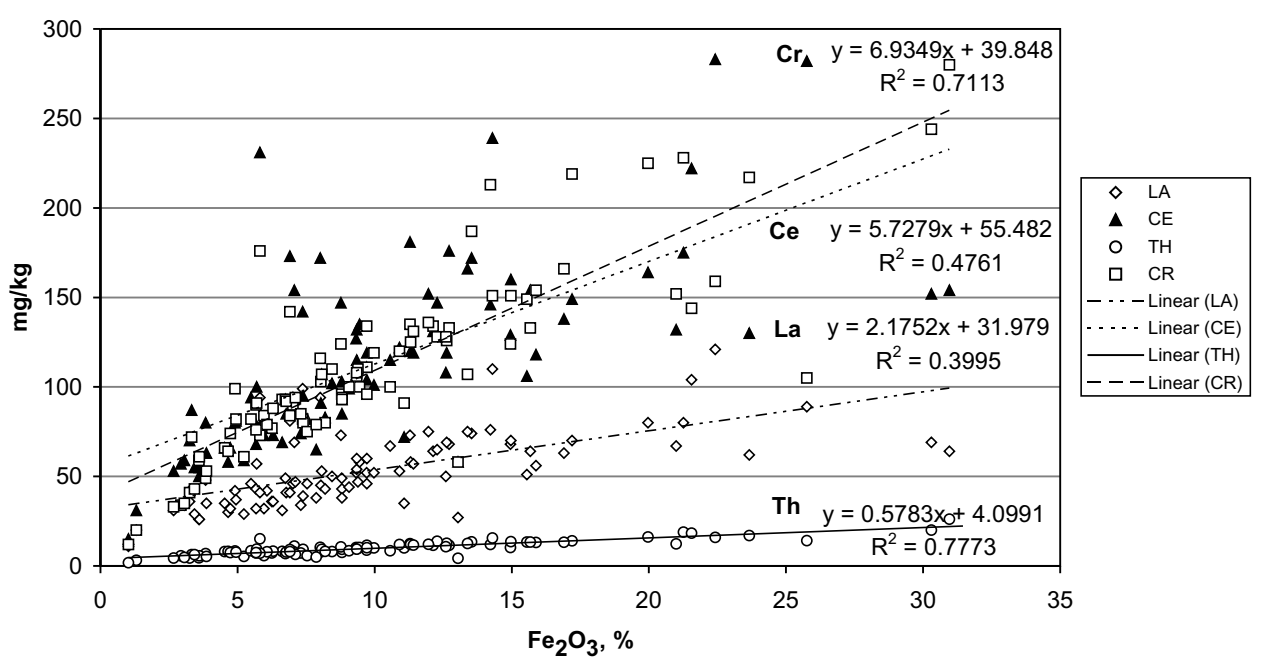

Frodingham Profile Soil: $\mathrm{Cr}, \mathrm{Ce}, \mathrm{La}$ and Th v Iron

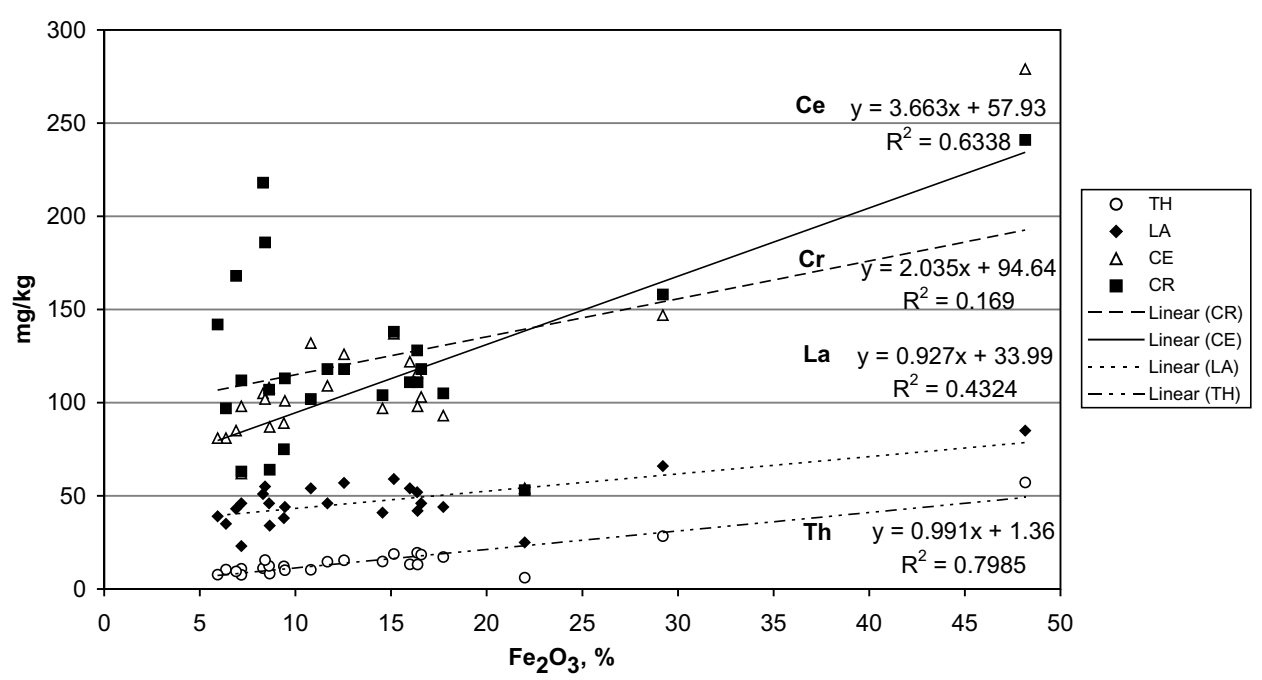

Marlstone Rock Profile Soil: Cr, Ce, La, Th v Iron

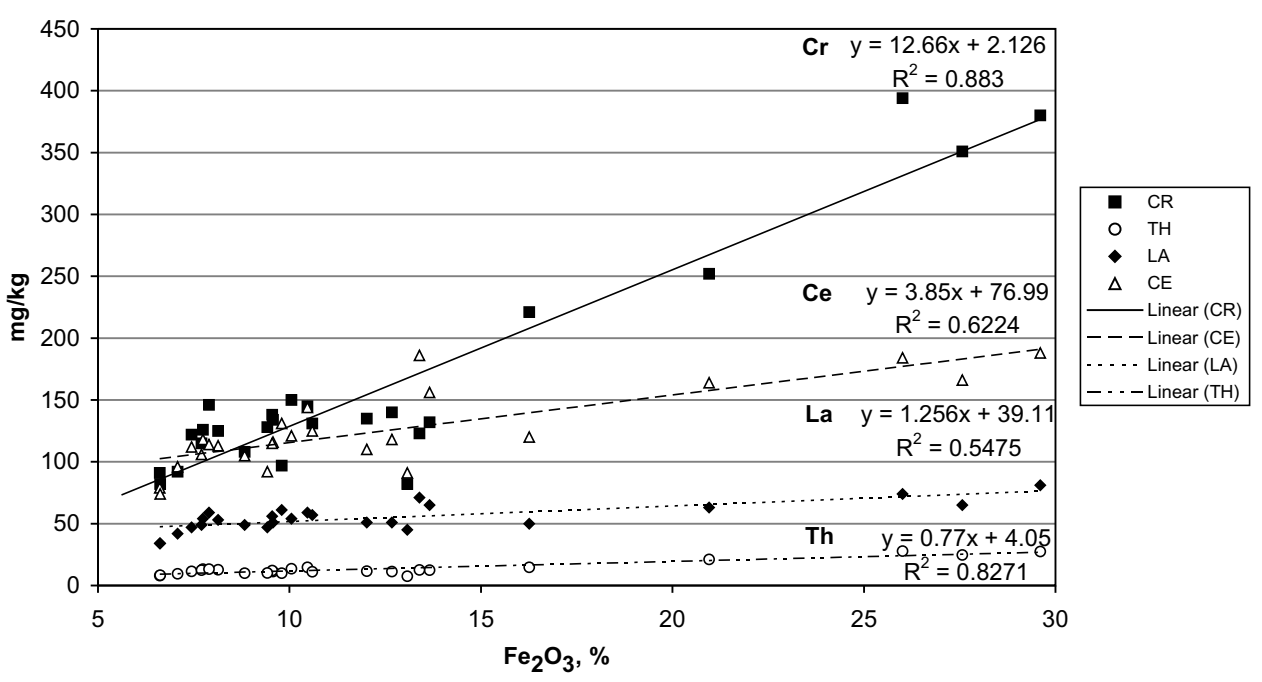

Fig. 13. Presumed 'resistate' trace elements in profile soils. 
As levels in the soils may comfortably exceed Soil Guideline Values, sometimes by an order of magnitude, there is unlikely to be any environmental impact from undisturbed ground and any 'remediation' carried out for development could be counterproductive. The pattern of elevated levels of $\mathrm{V}$ associated with the ironstones suggests a co-precipitation enhancement similar to that of As, rather than a resistate heavy-mineral source. Although elevated levels of $\mathrm{Cr}, \mathrm{Ce}, \mathrm{La}$ and $\mathrm{Th}$ were initially presumed to be due to resistate heavy minerals, a strong correlation with $\mathrm{Fe}$ in profile soils suggests that additional mobilisation, transport and concentration processes may have been operating during the formation of the ironstones. The mechanisms for the mobilisation of such elements as $\mathrm{La}, \mathrm{Ce}$ and $\mathrm{Th}$ are still not well known and are worthy of further investigation, especially since modern analytical methods such as ICP-MS now allow the detection of such metals in natural waters at much lower levels than was previously available. The local depositional environment and sediment source may be responsible for the especially high As content of the soils and sediments derived from the Claxby ironstone. The impact of industry and agriculture affects the primary geogenic linkages in some cases, especially for $\mathrm{P}$.

\section{Acknowledgements}

To all current and previous staff of the G-BASE project, including student voluntary workers, who were involved in the sample collection, preparation, analysis, processing, databasing and map production for the Humber-Trent regional survey. This paper is published with the permission of the Executive Director, British Geological Survey (NERC).

\section{References}

Alloway, B.J. (Ed.), 1995. Heavy Metals in Soils, second ed. Blackie Academic and Professional, Glasgow.

Breward, N., 2003. Heavy-metal contaminated soils associated with drained fenland in Lancashire, UK, revealed by BGS Soil Geochemical survey. Appl. Geochem. 18, 16631670.

Breward, N., Herd, R., 1998 (revised edition, 2005). Report on the development of NIH-Image for processing and examining geochemical data. Brit. Geol. Surv. Rep. WP/98/007.

Brookins, D.G., 1988. Eh-pH Diagrams for Geochemistry. Springer-Verlag, New York.

British Geological Survey, 2007. Regional Geochemistry of the Humber-Trent region, UK. (On CD-ROM). British Geological Survey, Nottingham UK.
Cave, M.R., Wragg, J., Palumbo, B., Klinck B.A., 2003. Measurement of the bioaccessibility of arsenic in UK soils. Environment Agency, UK, P5-062/TR1.

Chenery, S.R.N., Phillips, E.R., Haggerty, G., 2001. An evaluation of geochemical fingerprinting for establishing the provenance of Scottish Red Ware Pottery. Medieval Ceramics 25, 45-53.

DEFRA, 2002. Soil guideline values for arsenic contamination. Department for the Environment, Food and Rural Affairs, UK. SGV1.

Dixit, S., Hering, J.G., 2003. Comparison of $\operatorname{arsenic}^{(\mathrm{V})}$ and arsenic $^{(\mathrm{III})}$ sorption onto iron oxide minerals: Implications for arsenic mobility. Environ. Sci. Technol. 37, 41824189.

Fordyce, F.M., Brown, S.E., Ander, E.L., Rawlins, B.G., O'Donnell, K.E., Lister, T.R., Breward, N., Johnson, C.C., 2005. GSUE: Urban geochemical mapping in Great Britain. Geochem. Explor. Environ. Anal. 5, 325-336.

Hamon, R.E., McLaughlin, M.J., Gilkes, R.J., Rate, A.W., Zarcinas, B., 2004. Geochemical indices allow estimation of heavy metal background concentrations in soils. Global Biogeochem. Cycles 18, GB1014.

Hutchins, M.G., Smith, B., Rawlins, B.G., Lister, T.R., 1999. Temporal and spatial variability of stream waters in Wales, the Welsh Borders and part of the West Midlands, UK. 1. Major ion concentrations. Water Res. 33, 34793491.

Johnson, C.C., Breward, N., 2004. G-BASE: Geochemical Baseline Survey of the Environment. British Geological Survey Commissioned Report, CR/04/016N.

Johnson, C.C., Breward, N., Ander, E.L., Ault, L., 2005. G-BASE: Baseline geochemical mapping of Great Britain and Northern Ireland. Geochem. Explor. Environ. Anal. 5, 347-357.

Maynard, J.B., 1983. Geochemistry of Sedimentary Iron Deposits. Springer, New York.

Palumbo-Roe, B., Cave, M.R., Klinck, B.A., Wragg, J., Taylor, H., O'Donnell, K.E., Shaw, R.A., 2005. Bioaccessibility of arsenic in soils developed over Jurassic ironstones in eastern England. Environ. Geochem. Health 27, 121-130.

Rawlins, B.G., Lister, T.R., Mackenzie, A.C., 2002. Trace-metal pollution of soils in northern England. Environ. Geol. 42, 612-620.

Rawlins, B.G., Webster, R., Lister, T.R., 2003. The influence of parent material on top-soil geochemistry in eastern England. Earth Surf. Proc. Landforms 28, 1389-1409.

Rawson, J.F., 1992. The Cretaceous. In: Duff, P.M.D., Smith, A.J. (Eds.), Geology of England and Wales. The Geological Society, London.

Ruby, M.V., Davis, A., Schoof, R., Eberle, S., Sellstone, C.M., 1996. Estimation of lead and arsenic bioavailability using a physiologically-based extraction test. Environ. Sci. Technol. 30, 422-430.

Stone, P., Breward, N., Merriman, R.J., Plant, J.A., 2004. Regional geochemistry of cryptic geology: Variations in trace element distribution across the Southern Uplands terrane, Scotland. Appl. Earth Sci. (Trans. Inst. Min. Metall. Section B) 113, B43-B57.

Tipping, E., 1998. Humic ion-bonding model VI: An improved description of the interactions of protons and metal ions with humic substances. Aquat. Geochem. 4, 3-48.

Tye, A.M., Cave, M.R., Kinniburgh, D.G., in preparation. An assessment of the mobility, speciation and bio-accessibility of As in disturbed urban soils overlying Lincolnshire ironstones. 
Wragg, J., 2005. A study of the relationship between bioaccessibility and its solid phase distribution in soils. Unpublished Ph.D. Thesis. Univ. Nottingham, UK.
Young, T.P., Taylor, W.E.G. (Eds.), 1989. Phanerozoic ironstones. Spec. Publ. 46, Geological Society of London. 